\title{
Understanding Trends in Population Health
}

To understand trends in population health, and to decide between different explanations, it is necessary to have a good theory for what determines population health. In this chapter we therefore review the available theories, and compare some of their predictions with our European data. We end this chapter with an overview of the historical development of public health and medical care, and of its impact on population health in Europe.

\section{Theories of Population Health}

Before we can understand long-term trends in population health, we must understand what the causes of disease are. Of course, different specific diseases have different specific causes, but is there no general theory of what causes disease in human beings?

Unfortunately, this general theory is hard to find. Unlike physicists, who spend huge research budgets on finding a 'Theory of Everything' which explains all physical aspects of the universe, health scientists do not seem interested in a unified theory of what causes disease. One will look in vain for such a theory, or even a brief general introduction on the nature and origins of disease, in the textbooks of public health and epidemiology. ${ }^{1}$

What the public health literature offers us is a number of useful, but often shallow, conceptual frameworks. Starting from what we know about the many specific 'determinants' of disease as found in epidemiological studies, these frameworks propose a smaller number of more general categories of determinants of health and disease, plus - sometimes - an idea of how these groups of determinants relate to each other.

A simple example is the 'host-agent-environment' model, which was originally developed for a better understanding of infectious diseases. According to this model, infectious disease occurs when the environment brings an 'agent' (a micro-organism) in contact with a 'host' (a human being). The model

1 And, for that matter, in textbooks of pathology or general medicine. For a critique of the lack of theorizing in epidemiology, and a proposal for an 'ecosocial theory of disease distribution', see Nancy Krieger, Epidemiology and the People's Health (Oxford etc.: Oxford University Press, 2011). 
suggests that differences in the occurrence of infectious disease can be explained from differences in characteristics of the agent (e.g., the virulence of the micro-organism), the host (e.g., his or her levels of immunity), and the environment (e.g., contamination of drinking water). ${ }^{2}$

After the near-elimination of infectious diseases, epidemiological textbooks adopted a similar conceptual framework for the understanding of chronic diseases, such as cardiovascular disease and cancer. This was done by introducing new types of 'agents', such as 'nutritive excesses' (causing cardiovascular disease and diabetes), allergens (causing asthma and hay fever), and ionizing radiation (causing leukaemia). Although the host-agent-environment model provided no structure for how to understand the interaction between its three components, it did help to emphasize the continuing importance of factors external to the 'host'.

Later, more complex frameworks were proposed, such as that of the 'web of causation' which allows for a larger number of determinants of each disease, some of which may work indirectly through other determinants. This model recognizes that diseases are often caused by a chain of different factors. For example, diabetes may be due to obesity, which may be due to a high-calorie diet, which may be due to high sugar content of food stuffs, which may be due to consumers' preference for both a nice taste and a low price. In addition, it allows for the possibility that different factors may have to come together to produce the outcome. In the diabetes example, the web of causation does not only include consumers' preferences but also producers' profit maximization strategies, which together help to understand why sugar is added to so many foodstuffs. ${ }^{3}$

These frameworks are - to a large extent - empty shells, but other conceptual frameworks have tried to organize environmental and other determinants of disease into a smaller number of groups, and to give labels to each group

2 According to Krieger, Epidemiology, p. 15o, the first explicit mention of 'host', 'agent' and 'environment' as factors determining the occurrence of disease dates to the early 1950s (Gordon JE. Epidemiology - old and new. Journal of the Michigan State Medical Society 1950; 49:194-99).

3 For an elaboration of the 'host-agent-environment' model for non-communicable diseases, see Abraham M. Lilienfeld and David E. Lilienfeld, Foundations of Epidemiology, Second ed. (Oxford etc.: Oxford University Press, 1981), pp. 46-47. The 'web of causation' model was proposed in MacMahon and Pugh, Epidemiology, pp. 23-24. Incorporating chains of causation often requires multi-level models, which take into account different levels of organization and thus allow for the influence of macro-level factors on micro-level behaviour. For an elaboration, see Mervyn Susser and Ezra Susser, "Choosing a Future for Epidemiology: Ii. From Black Box to Chinese Boxes and Eco-Epidemiology," American Journal of Public Health 86, no. 5 (1996): 674-77. 
pointing to more general causes of disease. For example, the 'Lalonde model' makes a simple distinction between four groups of factors: 'human biology' (including genetics), the 'environment', 'life style', and 'health care organization'. Another popular model, the so-called 'rainbow model', regards health and disease as the outcome of several layers of influences, graphically depicted as a rainbow. These run from an outer layer of 'general socioeconomic, cultural and environmental conditions', through 'living and working conditions', 'social and community networks', and 'individual lifestyle factors', to an innermost and more immutable part of 'age, sex and constitutional factors'. Recently, a more detailed model of the 'social determinants of health' was proposed by the wHо Commission of the same name. This links the 'socioeconomic and political context' to inequalities in 'social position', and these to inequalities in specific living conditions, and these to inequalities in health and well-being. ${ }^{4}$

All these models usefully emphasize that diseases are often caused by external influences, however defined. This clearly resonates with one of the main findings of this book, which is that diseases tend to rise and fall on a time-scale too short to allow for spontaneous changes in the internal structure and functioning of the human body. Such an 'ecological' view of disease causation has deep historical roots, ultimately going back to Hippocrates' account of the environmental causes of disease in his famous Airs, Waters and Places.

In this treatise, Hippocrates (c. 460-377 BCE) described the important effects of climate, diet and other environmental conditions on health and disease in the ancient Greek world. This view of disease causation was revived and further elaborated in the 18th century, and is still relevant and valid today, although the details of the links between the environment and disease have undergone a complete re-think. ${ }^{5}$

4 What came to be known as the 'Lalonde model' was proposed in a report issued in 1974 under the responsibility of the then Canadian Minister of Health Marc Lalonde; see Trevor Hancock, "Lalonde and Beyond: Looking Back at 'a New Perspective on the Health of Canadians," Health Promotion International 1, no. 1 (1986): 93-100. The 'rainbow model' was proposed in 1991 in Göran Dahlgren and Margaret Whitehead, Policies and Strategies to Promote Social Equity in Health (Stockholm: Institute for Future Studies, 1991). The 'social determinants of health' model was first published in Commission on Social Determinants of Health, Closing the Gap in a Generation (Geneva: World Health Organization, 2008), p. 43. Later versions also include a 'life-course' perspective, e.g., in Michael Marmot et al., "wHo European Review of Social Determinants of Health and the Health Divide," Lancet 380, no. 9846 (2012): 1011-29.

5 For Hippocrates' Airs, waters and places, see, e.g., Dona Schneider and David E. Lilienfeld, eds., Public Health: The Development of a Discipline (New Brunswick etc.: Rutgers University Press, 2011), Chapter 2. The emergence of 'public hygiene' in the 18th century can be seen as a revival of Hippocratic ideas (James C. Riley, The Eighteenth Century Campaign to Avoid Disease (New York: St. Martin's Press, 1987)). This is illustrated by the work of the French 
This is illustrated by two more recent attempts to develop a general theory of the origins of disease. The first is by French-American microbiologist René Dubos (1901-1982), who published a couple of profound books on human health and its determinants in the 1950s and 1960s, such as Mirage of Health (1959) and Man Adapting (1965). The following citation from Man Adapting summarizes Dubos' main line of reasoning: "[S]tates of health or disease are the expressions of the success or failure experienced by the organism in its efforts to respond adaptively to environmental challenges" (p. xvii). Dubos underpins this statement by an in-depth analysis of the effects on human health of a wide range of 'environmental challenges', including climate extremes, social competition, malnutrition, microbes, and water and air pollution.

Dubos also discusses the 'rise-and-fall' of diseases, which he relates to the dynamic nature of these environmental challenges. He explains the emergence of 'new' diseases in his own life-time as follows:

To a surprising extent, modern man has retained unaltered the bodily constitution, physiological responses, and emotional drives which he has inherited from his Paleolithic ancestors. Yet he lives in a mechanized, airconditioned, and regimented world radically different from the one in which he evolved.

The diseases characteristic of highly industrialized and urbanized societies are, to a large extent, the manifestations of the effects of new environmental forces to which man has not had a chance to become adapted. $^{6}$

The second - and somewhat less profound - attempt at a general theory of the causes of disease is by Thomas McKeown, the same person whose work played such an important role in the 'battle of ideas' on the explanation of the increase in life expectancy in the Western world. In the final year of his life, long

proto-hygienist Jean-Noël Hallé (1754-1822) who classified the factors that modify health into circumfusa (things that surround us), applicata (things that are applied to our bodies), ingesta (things that are introduced into our bodies), excreta (things that we excrete), gesta (our voluntary actions), and percepta (our perceptions). See Gérard Jorland, Une Société à Soigner (Paris: Gallimard, 2010), Chapter 2.

6 Dubos, Man Adapting; citations are from the 13th printing (1977), p. xviii and p. 367. Dubos has criticized the 'utopian' idea that all diseases can be eliminated by environmental control, because man always seeks novelty and thereby exposes himself to new health risks; see René J. Dubos, Mirage of Health (New York: Harper \& Brothers, 1959), pp. 281-282. 
after he published his main work on the historical decline of mortality in England and Wales, he published an interesting book entitled The Origins of Human Disease. ${ }^{7}$

In this book, McKeown proposes to classify all diseases in just three categories: 'prenatal diseases' (all diseases manifested before birth), 'diseases of poverty' (diseases manifested after birth that are attributable to deficiencies or hazards related to lack of the essentials for life), and 'diseases of affluence' (diseases manifested after birth that are attributable to maladaptation or hazards related to industrialisation). His category of 'prenatal diseases' includes chromosomal aberrations, single-gene defects, and congenital malformations. Diseases of poverty' include malnutrition and infectious diseases. And 'diseases of affluence' include cardiovascular diseases, most cancers, diabetes, and other so-called 'western' diseases.

In all its simplicity (or simplism?), this classification rests on an explicitly ecological theory of disease causation. After setting aside congenital (and thus potentially genetically caused) diseases, this theory attributes all other diseases to a single etiological factor, of which one can have either too little or too much: prosperity. Of course, McKeown is careful in drawing out the multiple and often indirect links between economic development and the occurrence of disease, and to point out counterexamples and caveats. Yet, this is a parsimonious theory of the fundamental causes of all disease which - if correct explains why during economic development some diseases fall and others rise.

\section{An 'Ecological-Evolutionary Theory' of the Origins of Disease}

After this brief review it is possible - leaning heavily on Dubos - to sketch an 'ecological-evolutionary theory' of the fundamental causes of disease. A summary of this theory in one long sentence is: diseases are caused by 'unfavourable exchanges' between the human organism and its external environment, and/or by 'failures in the structural and functional design' of the organism, which, in the final analysis, are due to the dependence of human organisms on a fundamentally hostile external environment, and to unfortunate evolutionary legacies (Figure 5$) .8$

This theory of the 'origins of disease' starts from the recognition that, despite the enormous variety in the diseases that humans suffer from, all manifestations of disease can be understood as resulting from some 'pathologic onset'. This is an unbalancing change in the 'internal milieu' of the organism

7 McKeown, Origins.

8 This section has been modified after Johan P. Mackenbach, "The Origins of Human Disease: A Short Story on 'Where Diseases Come From,"' Journal of Epidemiology \& Community Health 6o, no. 1 (2006): 81-86. 


\section{Signs and symptoms}

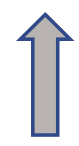

\section{Pathological onsets}

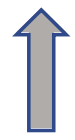

Unfavourable exchanges

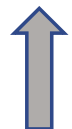

\section{Environmental hostilities}

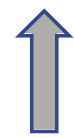

Design failures

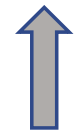

Evolutionary legacies

FIGURE 5 The origins of disease

ADAPTED FROM JOHAN P. MACKENBACH, “THE ORIGINS OF HUMAN DISEASE: A SHORT STORY ON 'WHERE DISEASES COME FROM.'” JOURNAL OF EPIDEMIOLOGY \& COMMUNITY HEALTH 60, NO. 1 (2006): 81-86

with which it cannot adequately cope, and which sets the whole disease process in motion. Disease processes, i.e., the internal mechanisms that produce the signs and symptoms of disease, are what medical textbooks are keen to describe in detail. However, these mechanisms find their starting-point in a 'pathologic onset', and only this can guide us in our search for the real causes of disease. For example, in the case of infectious diseases this 'pathologic onset' is invasion by micro-organisms, and in the case of cancer it is uncontrolled cell growth resulting from mutations in DNA. ${ }^{9}$

9 Disease processes usually consist of reactions of the organism to 'pathologic onsets'. Further examples of 'pathologic onsets' are: hereditary DNA abnormalities (leading to conditions like Down's syndrome, Huntington's disease), induction of auto-immune reactions (hyperthyroidism, rheumatoid arthritis), induction of allergic reactions (asthma, atopic eczema), nutrient deficiencies (iron-deficiency anaemia, pellagra), derangements of metabolic processes (diabetes), formation of atherosclerotic plaques (ischaemic heart disease, ischaemic stroke), cytogenetic abnormalities (lung cancer, leukaemia), mechanical 'wear-and-tear' to supportive structures (lumbar hernia, osteoarthritis), ingestion of 
The next question then is what causes these 'pathologic onsets', and the general answer is that these always result from an unfavourable exchange between the human organism and its external environment, or from a failure in the structural or functional design of the organism, or from a combination of both. Sometimes the unfavourable exchange with the external environment is easier to identify, as in the case of invasion by micro-organisms, or ingestion of noxious chemical substances causing poisoning, or encounters with large kinetic forces causing bone-fractures. In other cases the design failures are easier to recognize, as in the case of hereditary DNA abnormalities causing Huntington's disease, or allergic reactions causing asthma. Yet, as we will see below, deeper reflection often shows that both are necessary for disease to occur.

We can now go one step further, and ask ourselves why human organisms so often have unfavourable exchanges with the environment, and why their design so often has imperfections leading to disease. Let's start with the first question: why are unfavourable exchanges with the environment so common? This can only be understood if we realize that exchanges with the environment are necessary. In order to survive, all living organisms must continuously exchange energy and matter with their external environment, because these exchanges provide the organism with the basic necessities of life (food, oxygen, warmth and water). In addition, human organisms need their environment for material security (housing, income, safety, ...), social interaction (support, intimacy, status, ...), and self-development (knowledge, aesthetics, self-actualisation, ....). ${ }^{10}$

Many of these exchanges are favourable, but some are not. Health problems may arise, when the intake of basic necessities or the fulfilment of more advanced human needs is insufficient, or when, in its necessary exchanges with the environment, the human organism encounters noxious (harmful) influences. These 'noxae' can be physical in nature (noise, radiation, cold, ...), or chemical (pollutants, tobacco smoke, certain lipids, ...), or biological (parasites, bacteria, viruses, ...), or psychological (bullying, sexual abuse, ...). Almost all diseases can be traced back to one of these unfavourable exchanges, which may range from lack of a basic nutritional factor (causing pellagra) to ingestion of the wrong kind of lipids (ischaemic heart disease), and from encounters with a virus (influenza) to inhalation of tobacco smoke (lung cancer). ${ }^{11}$

noxious chemical substances (intoxication, alcoholic liver cirrhosis), and encounters with large kinetic forces (hip fracture, shot wounds).

10 The phrase 'unfavourable exchanges with the external environment' was chosen to include both insufficient intakes from the environment of the necessities of life, and encounters with noxious influences from the environment.

11 These exchanges with the external environment are usually active processes, and are therefore determined as much by the behaviour of the organism as by the environment 
But why are these unfavourable exchanges with the environment so common, that mankind is continuously plagued by an enormous variety of diseases? The disheartening answer is: because the external environment on which we depend is more hostile than we like to think. It is hostile in the sense that the basic and more advanced necessities for human flourishing are scarce, and in the sense that this environment contains an abundance of 'noxae'.

Earth has allowed life to develop, so it must be a relatively life-friendly planet. Yet, it has always been a challenge for mankind to find or grow sufficient food, and human societies have always had difficulty providing for the more advanced needs of all their members. This scarcity is partly natural, and partly man-made in the sense that the increase in human population numbers and human needs has tended to outpace the increase in available resources. And it is not only a matter of scarcity: paradoxically, the same elements in the abiotic, biotic and human environment that we are dependent on, often can make us sick as well.

A simple illustration of this paradox is oxygen: all higher life on earth is dependent on oxygen, but oxygen is a dangerous compound, as one can see from the fact that it destroys iron. During the processing of nutrients in our bodies, oxygen is released, and this causes 'oxidative stress' which is thought to contribute to cardiovascular disease and cancer. Another illustration: all life on earth is dependent on sunlight, but exposure to ultraviolet and other radiation leads to mutations in our DNA and may cause cancer.

There is also a fundamental hostility, in the form of competition, between different life-forms. Bacteria feed on us, and although we have developed sophisticated mechanisms of defence, they are smarter, and continuously succeed in circumventing our countermeasures. Equally important is the fact that, while we need other human beings for survival and flourishing, at all levels of human organization (families, companies, cities, countries, globally) we also compete with each other for resources, causing diseases in those who are less successful. ${ }^{12}$

The active role of mankind in producing its own diseases actually extends much further than the competition just mentioned. Exposure to a hostile

itself. The interaction between organism and environment blurs the distinction between the two; see Richard C. Lewontin, The Triple Helix (Boston: Harvard University Press, 2001).

12 For the role of 'oxidative stress' in generating cardiovascular disease and cancer, see Richard G. Cutler and Henry Rodriguez, Critical Reviews of Oxidative Stress and Aging (New York: World Scientific Publishing, 2003). Bacteria are not only hostile: we also need them, e.g., for digestion. For the role of human competition in health inequalities, see Johan P. Mackenbach, "Persistence of Social Inequalities in Modern Welfare States," Scandinavian Journal of Public Health 45, no. 2 (2017): 113-20. 
environment often results from seeking novel environments in which we hope to find a better life, but which contain dangers to which we do not yet have an adequate response. It also sometimes results from human interventions that are intended to improve living conditions, but as a side-effect harm the environment that we depend on. The shift from hunting-and-gathering to agriculture is an example of a change in which human beings have sought to escape one danger (lack of edible wild plants and prey animals), but replaced it with another (dependence on a limited number of cultivated plants and animals). Human development often seems like a forward flight in which frontiers are pushed backwards, but never disappear completely. ${ }^{13}$

While this suggests a purely 'ecological' view of disease causation, it is important to note that some cases of all diseases, and many cases of some diseases, may be entirely attributable to an autonomous derailment of internal mechanisms. This can be seen as a failure in the (genetically determined) structural or functional design of the human organism. Hereditary DNA abnormalities, such as those leading to Huntington's disease, are a clear example of diseases where most cases are probably attributable to such a design failure only, without much influence from the environment. But such examples are uncommon, and the importance of design failures - or perhaps better: design imperfections - in the causation of disease extends much further than their role in rare inherited disorders.

One important design imperfection is that human organisms cannot always cope effectively with unfavourable exchanges with the external environment. Our organism disposes of a large variety of protection and adjustment mechanisms, ranging from protective structures and detoxification mechanisms to immune reactions and behavioural responses. These are supposed to protect us from harm, and some failure of these adjustment mechanisms can therefore usually be identified when disease occurs. For example, invasion of microorganisms only produces infectious disease when the immune system does not succeed in timely elimination of the invaders - which often happens, indicating that our immune system is imperfect. Similarly, the fact that we sometimes break our bones indicates that our protective structures have not been designed to withstand all the kinetic forces that we encounter. ${ }^{14}$

13 Other examples range from the migration out of Africa which opened up new continents for human exploitation but also exposed humans to colder and less sunny climates, to industrialization which massively increased the production of basic necessities but also polluted the environment; see Anthony J. McMichael, Human Frontiers, Environments and Disease (Cambridge etc.: Cambridge University Press, 2001). For novelty-seeking, see Dubos, Mirage of Health.

14 The distinction between 'unfavourable exchanges with the external environment' and 'design failures' is similar to that between 'nurture' (external environment) and 'nature' 
But design failures are not limited to those which interfere with our responses to the external environment. Another design imperfection is that living organisms cannot deal perfectly with 'entropy'. Survival requires constant reproduction - of germ cells (for creating progeny) and of somatic cells (for repair and maintenance of our bodies). However, during cell reproduction small random errors in DNA occur all the time. Although we have highly effective repair and search-and-destroy mechanisms, a small fraction of these errors is not detected in time, leading to congenital disease in our children or to cancer in ourselves. These and other design failures also partly explain why the incidence of many diseases rises with age: the combination of an accumulation of environmental insults with less-than-perfect defence and repair mechanisms ensures that disease risks go up when we age. ${ }^{15}$

Conceivably, due to the very success of improvements of the environment, the balance in the causation of human disease may over time have shifted somewhat from 'exogenous' to 'endogenous' causes, i.e., from a predominant role of unfavourable exchanges with the external environment, to a relatively more important role for design imperfections. The increased importance of neurological diseases like Alzheimer's dementia and Parkinson's disease, for which it has proved difficult to find environmental causes, may be an illustration of this shift. ${ }^{16}$

Purely 'ecological' theories of disease causation may thus be losing some of their explanatory power, but that environmental factors still play an important role is clear from their quantitative contributions to the burden of disease, also in high-income countries. ${ }^{17}$

We may then ask, like we did in the case of unfavourable exchanges with the external environment: why do human organisms have so many design imperfections? This question can best be answered from the perspective of

(genes). The distinction can be misleading, because the environment influences living organisms through their genes, and genes influence the way organisms interact with their environment; see Matt Ridley, Nature Via Nurture. Genes, Experience and What Makes Us Human. (London: Harper, 2004).

15 A third design failure is that we have limited supplies of vital stocks, such as immune cells that can be directed at specific antigens: after we have exhausted these supplies, we cannot cope with new micro-organisms any more. For the role of 'design failures' in the ageing process, see Robert E. Ricklefs and Caleb E. Finch, Aging: A Natural History (New York: Scientific American Books, 1995); Thomas B.L. Kirkwood, Time of Our Lives (Oxford etc.: Oxford University Press, 1999).

16 See Chapter 8.

17 For quantitative analyses of the contribution of 'exogenous' determinants to mortality and disability, see, e.g., G BD 2017 Collaborators, "Global, Regional, and National Comparative Risk Assessment of 84 Behavioural, Environmental and Occupational, and Metabolic Risks," Lancet 392 (2018): 1923-94. 
evolutionary biology. This lack of perfection is partly due to the fact that humans have not evolved to be able to live in good health in our current environment. The structural and functional characteristics of the human organism have been selected for their 'fitness' (i.e., ability for survival and reproduction) in previous hostile environments. Our organism can cope with hunger, and less so with the more recent abundance of food. ${ }^{18}$

Some of these 'imperfections' in our design are due to 'trade-offs' or compromises that were necessary during this long evolutionary trajectory. Sickle cell anaemia is the classic example. People heterozygous for the sickle cell gene, which causes an abnormality in haemoglobin (the oxygen-carrying protein in red blood cells), are protected from malaria, but have difficulty being physically active. On balance, this was advantageous when their ancestors lived in a malaria-infested environment, but has now become a disadvantage. Another example is familial hypercholesterolemia, which increases the risk for cardiovascular disease now, but probably provided protection against famine in the past.

More generally, the ubiquity of design imperfections is due to the fact that during humans' long evolutionary trajectories, achieving perfection was not necessary in the first place. This insight comes from the 'disposable soma' theory, which sees our bodies as nothing more or less than the 'throw-away' vehicles of our genetic material. The successful propagation of our genes does not require a perfect body at all, but only requires that we are able to reproduce before our bodies fall apart, due to the effects of a hostile environment and/or innate imperfections. ${ }^{19}$

\section{Explaining Long-term Change}

We are now in a better position to address the question that will concern us in the rest of this book: how to explain long-term trends in population health,

18 See, e.g., Randolph M. Nesse and George C. Williams, Why We Get Sick (New York: Times Books, 1995). For more extensive analyses, see Stephen C. Stearns, ed., Evolution in Health and Disease (Oxford etc.: Oxford University Press, 1999).

19 For the trade-off in familial hypercholesterolemia, see Eric J.G. Sijbrands et al., "Mortality over Two Centuries in Large Pedigree with Familial Hypercholesterolaemia," British Medical Journal 322, no. 7293 (2001): 1019-23. Another trade-off follows from the theory of 'antagonistic pleiotropy', which posits that senescence (and disease associated with senescence) is the inevitable by-product of adaptations that increase fitness earlier in life. For example, mechanisms that limit cellular proliferation may protect against cancer in adult life, but will promote degradation of organ function in old-age; see George C. Williams, "Pleiotropy, Natural Selection, and the Evolution of Senescence," Evolution 11 (1957): 398411. For the 'disposable soma' theory, see Thomas B.L. Kirkwood and Steven N. Austad, “Why Do We Age?," Nature 408, no. 6809 (2000): 233-38. 
in particular the 'rise-and-fall' of so many diseases? At a time-scale of centuries changes in the structural and functional design of the human organism are implausible, and therefore the answer must lie elsewhere. The explanation must lie either in changes in the way mankind has interacted with its environment (which may have either increased or decreased the occurrence of disease) or in changes in the way mankind has handled disease (which may have changed the outcome of the interaction between humans and their environment).

Of course, changes in the occurrence of disease and its consequences has many specific explanations. Many specific exchanges with the external environment are involved, and all of these may have changed, from exposure to famine to working conditions and consumption patterns. Similarly, many specific interventions have been developed, often based on new scientific insights and technological breakthroughs. The latter are the usual stuff of histories of medicine and public health, and their development over time is certainly important for an understanding of the history of population health. Many of these specific changes will therefore be reviewed in the disease-focused chapters in part II of this book.

However, for a deeper understanding of long-term changes in population health we need a second level of explanation which helps us understand why these specific factors changed over time, often simultaneously and in similar directions. For this we need to move from the specific or 'proximal' factors just mentioned, to the more 'distal' factors which have set all the specific changes in motion.

Broadly speaking, the main candidates are economic and sociocultural change (which may have induced changes in the way mankind interacted with its environment) and the development of effective systems of health intervention (which enabled mankind to prevent diseases and their consequences, and to make human health somewhat independent from interactions with the environment). To the extent that these changes relied on collective human action, political changes may have played a role as well (both by fostering progress, for example by creating conditions for economic growth and investments in a public health infrastructure, and by causing temporary setbacks). ${ }^{20}$

These are the four groups of factors that we will introduce in the subsequent sections of this chapter. Separating out one of these as the main cause of

20 Omran already wrote that " $\mathrm{t}] \mathrm{h}$ he determinants of the transition from infectious to degenerative disease predominance are by no means simple," but include "[s]ocioeconomic, political and cultural determinants" and "[m]edical and public health determinants" (Omran, “Epidemiologic Transition", pp. 518-20). 
changes in population health is difficult, because they are interdependent and each has specific pathways linking it to long-term changes in European population health. Nevertheless, after reviewing all the evidence we will try to identify the 'prime mover' of these changes, but we delay that to one of the final sections of this book.

\section{Economic, Political and Sociocultural Conditions}

\section{Economic History: Improvements in Living Standards}

The increase in European life expectancies coincided with a strong increase of countries' living standards. Between 1700 and 1870, North-western European countries went through radical economic changes which started a period of unprecedented economic growth. These changes, usually summarized as the 'Industrial Revolution', started in Britain, spread from there to other parts of Western and Northern Europe, and after 1870 also spread to the South and East. Steam-power, factories, railways and globalization all contributed to the increase in economic productivity, which led to increases in real wages and public expenditure, but also to profound societal changes such as urbanization and secularization. ${ }^{21}$

Long-term trends in national income have been spectacularly upwards. Despite interruptions by two World Wars, the Great Depression of the 1930s, and the economic crises of the 1990s in Central-eastern, South-eastern and Eastern Europe, Europeans now enjoy much higher living standards than their ancestors in the second half of the 19th century. Some countries have changed their relative positions, such as the United Kingdom which lost its top position in the 1940s, and Portugal which moved from the rear-guard to a middle position after World War II. Other countries, such as Albania, retained their positions throughout these three centuries (see Suppl. Figure 6).

21 Economic historians have come to distinguish an 'industrious revolution' preceding the 'industrial revolution', which increased production and consumption by making family labour more efficient (Jan de Vries, "The Industrial Revolution and the Industrious Revolution," Journal of Economic History 54, no. 2 (1994): 249-70). For an introduction to European economic history, see Stephen Broadberry and Kevin H. O'Rourke, eds., Cambridge Economic History of Modern Europe: Volume 1: 1700-1870. (Cambridge etc.: Cambridge University Press, 2010). Stephen Broadberry and Kevin H. O'Rourke, eds., Cambridge Economic History of Modern Europe. Volume 2: 1870 to the Present (Cambridge etc.: Cambridge University Press, 2010); These volumes also contain insightful analyses of the impact of economic growth on population health. 
These improvements in living standards led to more and better nutrition, better housing, more leisure time, higher levels of education, and changes in many other aspects of life. Higher living standards are enjoyed throughout Europe - despite continuing and sometimes widening inequalities between countries - and throughout national populations - despite continuing and sometimes widening inequalities in income between social groups. Life is much better now than it used to be, but at the beginning of the 21st century we have become aware of many more "despites" than continuing inequalities.

Let's therefore pause for a moment and acknowledge some of the darker sides of this economic growth. Europe's economic advance would have been less propitious without the exploitation of its colonies in Africa, Asia and the Americas, often involving the use of slaves and brutal repression of indigenous peoples. The industrial revolution and all that followed would have been impossible without the burning of fossil fuels like coal and oil, ultimately leading to planetary climate change. Economic growth was also accompanied by massive environmental degradation and habitat destruction, leading to the extinction of many other living species. These are big issues to which we will need to come back (in Chapter 8).

For the moment, however, let's focus on the human health effects of economic growth. There can be little doubt that the resulting improvement in living conditions has brought many health benefits. The parallel upward movement of national income and life expectancy is striking, and certainly suggestive of a causal relationship between the two. So is the occurrence of simultaneous setbacks, as in the case of the declining life expectancies and average incomes in Central-eastern, South-eastern and Eastern Europe after the collapse of the Soviet Union.

There are several mechanisms that could explain such a causal relationship. Improvements in living standards helped to push back the diseases of the past that were caused by a lack of basic necessities, for example by eliminating famine and improving the quality of nutrition. Furthermore, economic growth allowed countries to invest in research and development, to create an expensive public health infrastructure, and to pay for rising costs of medical care. Through these and other pathways, economic development very likely contributed to long-term improvements in population health. ${ }^{22}$

However, upon closer inspection the relationship is far from straightforward, and the idea that economic growth automatically brings improvements in population health - still popular in public health circles - has been discredited

22 See, e.g., Lant Pritchett and Lawrence H. Summers, "Wealthier Is Healthier," Journal of Human Resources 31, no. 4 (1996): 841-68. 
by more in-depth studies. As we saw in Chapter 1, Preston's finding of strong upward shifts in the association between national income and life expectancy already fuelled scepticism about a causal link. These upward shifts appeared to be more important for the explanation of the secular increase in life expectancy, than the increase in national incomes per se. Later studies have fed this scepticism even further, and have demonstrated that a distinction needs to be made between short-term and long-term effects of economic growth, and between cross-sectional and longitudinal relationships between average income and population health.

Whereas the long-term effect of economic growth on population health must have been positive, the short-term effects have often been negative. This was as true in the 19th century as it is now. In the 19th century, rapid economic growth often reduced population health, because in their early phases industrialization and urbanization had many negative side-effects, such as occupational hazards, air pollution, and infection. Working conditions of labourers were often extremely poor, contaminated by dangerous substances and involving high injury risks. Factories also spewed gigantic amounts of smoke into their immediate surroundings. Living in crowded houses in the rapidly expanding cities multiplied the risks of air- and water-borne infections. These negative side-effects had to be actively counteracted by public health and other measures before the ultimate benefits could get the upper hand.

In the 2oth century, the short-term effects also were often negative. Economic expansion and contraction often had 'pro-cyclical' effects, in the sense that mortality usually went up during economic booms (because of an increase in, e.g., road traffic injuries and alcohol-related mortality) and went down again during recessions. Even on the longer time-scale of decades instead of years, economic growth has had many negative health effects, as economic development during the 2oth century was accompanied by air pollution and other forms of environmental degradation, and by rises in smoking, obesity and other risk factors implied in the term 'diseases of affluence. ${ }^{23}$

23 For an analysis of how rapid economic growth in the 19th century often caused "Disruption, Deprivation, Disease, and Death," which needed to be counteracted by public health and other countermeasures, see Simon Szreter, "Economic Growth, Disruption, Deprivation, Disease, and Death," Population and Development Review 23, no. 4 (1997): 693-728. Reconstruction of English life expectancy data for the first half of the 19th century clearly shows a deterioration in the first stages of the Industrial Revolution; see Simon Szreter and Graham Mooney, "Urbanization, Mortality, and the Standard of Living Debate," Economic History Review 51, no. 1 (1998): 84-112. For the effect of economic recessions on population health, see Christopher J. Ruhm, "Are Recessions Good for Your Health?" Quarterly Journal of Economics 115, no. 2 (2000): 617-50. For an analysis linking the rise of 
A distinction must also be made between cross-sectional and longitudinal relationships. We almost always find a strong relationship between national income and life expectancy at one point in time, as illustrated by the 'Prestoncurve.' However, the association between changes over time in national income and life expectancy is much weaker. For example, the Great Depression of the 1930s, in which national incomes temporarily declined, coincided with massive increases in life expectancy. More formal studies have also not been able to demonstrate that increases in national income consistently go together with increases in life expectancy. This implies that we cannot assume a causal relationship from rising national income to rising life expectancy, and that the cross-sectional relationship that we observe is probably determined by other mechanisms as well. ${ }^{24}$

One possibility is confounding by third factors. Higher life expectancy may have been produced by other factors that were associated with economic growth, but not caused by economic growth. One possibility is rising levels of literacy and education, which on the one hand helped economic growth, by increasing the productivity of the work-force, and on the other hand promoted population health improvements, by facilitating the diffusion of modern hygienic insights.

Another mechanism which may contribute to a strong cross-sectional association between national income and life expectancy, even in the absence of a strong effect of rising national income on life expectancy, is 'reverse causality'. This occurs if there is an effect of rising life expectancy (or population health improvement more generally) on national income. Studies have found convincing evidence for such 'reverse' effects, which are probably due to the fact that better health leads to higher labour productivity. The mutually reinforcing effects of population health on national income and vice versa can, in this way, give rise to 'virtuous cycles' underpinning longer periods of sustained growth in both. ${ }^{25}$

so-called 'diseases of affluence' to economic development, see Majid Ezzati et al., "Rethinking the 'Diseases of Affluence' Paradigm," PLoS Medicine 2, no. 5 (2005): e133. As American economist and Nobel laureate Angus Deaton has argued, despite short- and mid-term negative effects, economic growth has in the long run led to better population health; see Angus Deaton, The Great Escape (Princeton: Princeton University Press, 2013).

24 For a more rigorous 'longitudinal' analysis relating changes over time in national income to changes over time in life expectancy, see William Easterly, "Life During Growth," Journal of Economic Growth 4, no. 3 (1999): 239-76.

25 For an overview of empirical studies of the effects of life expectancy on economic growth, and the mechanisms involved, see David E. Bloom and David Canning, Population Health and Economic Growth, vol. 24, Health and Growth, (Washington, DC: World Bank (Commission on Growth and Development), 2009). A recent addition to this literature is 
A further complication - loosening a cross-sectional link between national income and life expectancy - is diffusion of knowledge and technology. As we have seen in Chapter 1, Preston's interpretation of the upward shift of the life expectancy curve between the 1930s and 1960 s was, that this was due to the diffusion of new technologies, such as malaria control and antibiotics. These spread from the richer countries in which they had been developed, to poorer countries which had not been able to pay for their development, but could now apply them at low cost.

The partial decoupling of technological advances from economic growth may also explain the rapid improvements of life expectancy during the Great Depression in the 1930s. These advances were probably due to innovations (such as sanitation, workers' protection, and better obstetric care) that had been introduced earlier, but had their full population health impact only in the 1930s. $^{26}$

Armed with these insights, we will now have a more detailed look at the European experience, starting with some cross-sectional 'Preston-curves'. The available data cover a very long period, from the 1870 s to the 2010s, of which just a few important time-points are shown in Figure 6.

In the $1870 s$, just before rapid increases in national income and life expectancy began, there was not yet a correlation between the two: European countries with a higher national income, such as Great Britain, did not have a higher life expectancy than poorer countries, such as Sweden or Norway. A positive correlation gradually emerged in the following decades, and is then consistently found from the 1930s onwards. This consistency is surprising, because

Matteo Cervellati and Uwe Sunde, Demographic Change and Long-Run Development (Cambridge (Mass.) \& London: MIT Press, 2017). When health gains are achieved within working ages, population health improvements may produce a 'demographic dividend' (David E. Bloom, David Canning, and Jaypee Sevilla, Economic Growth and the Demographic Transition, NBER Working Papers, (Cambridge, Mass: National Bureau of Economic Research, 2001)). Such 'virtuous cycles' are much less plausible for health improvements at higher ages.

26 For how technological advances have contributed to decoupling of life expectancy trends from economic growth, see David E. Bloom and David Canning, "Commentary: The Preston Curve 30 Years On: Still Sparking Fires," International Journal of Epidemiology 36, no. 3 (2007): 498-99. For the role of delayed effects in explaining the paradox of increasing life expectancy despite economic turbulence in the interwar period, see Robert Millward and Joerg Baten, "Population and Living Standards, 1914-1945," in Cambridge Economic History of Europe. Volume 2, ed. Stephen Broadberry and Kevin H. O'Rourke (Cambridge etc.: Cambridge University Press, 2010). The importance of literacy and education has been demonstrated in studies of rapid mortality declines in Kerala, Sri Lanka and Costa Rica; see John C. Caldwell, "Routes to Low Mortality in Poor Countries," Population and Development Review 12, no. 2 (1986): 171-220. 
Life expectancy vs national income, men

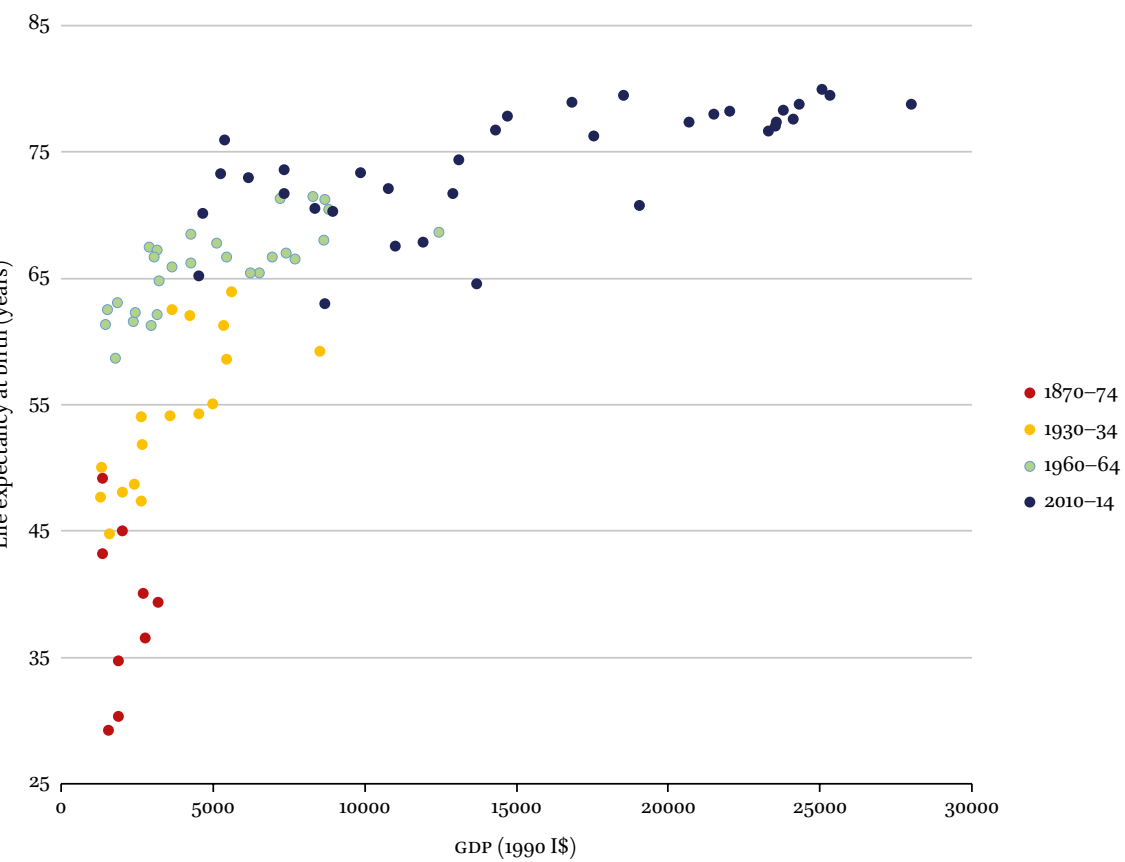

FIGURE 6 National income and life expectancy in Europe, 1870s to $2010 \mathrm{~s}$

Notes: Each dot represents one country/period combination

SOURCE OF DATA: WWW.CLIO-INFRA.EU FOR GDP (ACCESSED 28/08/2018),

HUMAN MORTALITY DATABASE AND MANY OTHER SOURCES FOR LIFE

EXPECTANCY

the cause-of-death composition of mortality changed radically. In the $1930 \mathrm{~s}$ and 196os, countries with a higher national income had lower infant mortality and mortality from infectious and respiratory diseases, whereas in the 1990 s and 2010 s they had lower mortality from cardiovascular diseases. ${ }^{27}$

Figure 6 also shows the large upward shifts in the relation between national income and life expectancy. Because national income has been expressed in

27 For the correlations between national income and life expectancy, see Suppl. Table 3. Simple correlations were statistically significant and positive in 1930-34, 1960-64, 199094 and 2010-14, but not in 1870-74 or 1900-04. After adjustment for other determinants (protestant legacy, average education, and level of democracy), statistically significant associations are only found in 1990-94 and 2010-14, suggesting that the effect of national income on life expectancy has become stronger, not weaker, over time. For a more indepth analysis, see Johan P. Mackenbach and Caspar W.N. Looman, "Life Expectancy and National Income in Europe, 1900-2008," International Journal of Epidemiology 42, no. 4 (2013): 1100-10. 
1990 international dollars, we can clearly see that at the same level of national income life expectancy was higher in the 2010s than the 196os, and in the 1960s than the 1930s. This implies that increases in national income provide at most a partial explanation of increases in life expectancy. ${ }^{28}$

Diffusion of new public health and medical technologies from richer to poorer countries in Europe - the mechanism postulated by Preston - has certainly played a role in these upward shifts. In several periods, particularly the 1930-1960 period, countries with a lower national income had larger increases in life expectancy than richer countries, due to stronger declines of infant mortality and mortality from infectious and respiratory diseases. In later sections and chapters, we will repeatedly come back to this remarkable catch-up phenomenon, which was based on rapid implementation in poorer countries of techniques and policies that had already been introduced in richer countries. ${ }^{29}$

As mentioned above, we cannot assume that the cross-sectional relationships seen in Figure 6 are due to a causal effect of national income on life expectancy. The nearest we can get to identifying a causal relationship is by relating changes-over-time in national income to changes-over-time in life expectancy. When we do this in our European dataset, we find positive relationships in the 1900-1930 and 1990-2010 periods only, suggesting that in these two periods, but not in others, rising living standards may have contributed more directly to rising life expectancy. ${ }^{30}$

Over-all, the European experience suggests that improved living conditions did play a role, but may not have been the most important factor in long-term improvements in population health.

\section{Political History: The Rise of the Modern State}

One other factor that has played a role is political change. Political conditions, events and actors have often facilitated or hindered population health

28 Although upward shifts occurred in all periods, they were largest in the period $1930-1960$, when they accounted for between two-thirds and four-fifths of the increase in life expectancy in Europe as a whole. As shown in Mackenbach and Looman, "Life Expectancy", after 1960 the upward shifts were smaller, and contributed between one-quarter and onehalf to the increase in life expectancy in Europe as a whole.

29 For the correlations between national income at the beginning of each period, and changes in life expectancy during each period, see Suppl. Table 3 .

30 For the correlations between changes in national income and changes in life expectancy, see Suppl. Table 3. These correlations were statistically significantly negative in 1930-1960, and mostly non-significant in other periods, suggesting that the catch-up in 1930-1960 by poorer countries was independent of improvements in living standards. 
improvements, either directly or indirectly. In the few pages that follow, we will focus on two important political developments: the development of the modern state, and changes in the governance of states (particularly the rise of democracy and the adoption of egalitarian ideologies). ${ }^{31}$

The development of the modern state has been given extra emphasis in the title of this section, because it provided the necessary institutions and resources for implementing large-scale measures to improve population health, from sewage systems to old-age pensions and from universal health insurance to road safety. However, without the rise of democracy and of egalitarian ideologies the health benefits would not have been so wide-spread. This increased the leverage of the poorer sections of society, which led to policies and institutions benefiting the health of all, and not only that of the elites. As a result, and as we will see below, differences between European countries in the timing, speed and direction of political change often went together with differences in the timing, speed and direction of population health change.

General histories of Europe agree that the development of the modern state was one of the most significant developments of the 18th and 19th centuries. The 18th century saw the emergence of centralized states with uniform taxation, professional bureaucracies, and a gradually expanding scope for national policies. Apart from maintaining an increasingly costly army, these policies came to include the improvement of communications, the promotion of trade, and the containment of epidemics. During the 19th and 2oth centuries, European states were further strengthened by promotion of a national consciousness, rising levels of taxation, and a relentless expansion of the responsibilities of the state. These now also came to include the provision of education, social security, mother and child care, health insurance, and many other public policies that most Europeans now take for granted.

These trends were not primarily driven by considerations of public welfare, but by what was perceived to be the national interest. Due to technological developments, warfare became more and more costly, and these costs could only be carried by a centralized state capable of raising taxes. Investments in roads, waterways and (in the 19th century) railways were justified by the necessity of stimulating economic growth. The expansion of the welfare state was not only a means of relieving poverty, but also of containing communism and warding off revolution. Nevertheless, increasing government involvement

$31 \quad$ War - "the mere continuation of politics by other means," according to Prussian general Carl von Clausewitz (1780-1831) - will be dealt with in Chapter 4. 
(and effectiveness) was an important pre-condition for many policies that sooner or later improved public welfare, including population health. ${ }^{32}$

The political map of Europe has undergone enormous changes in the course of the centuries covered by this book. In the early 18 th century no such thing as Germany or Italy existed yet, Finland was still part of the Kingdom of Sweden, the Ottomans occupied large parts of the Balkans, and the Polish-Lithuanian Commonwealth contained a huge part of Central-eastern and Eastern Europe, until it was partitioned between Russia, Prussia and the Habsburg empire and completely erased from the map at the end of the 18th century.

During the 19th and 2oth centuries, Europe's political map was repeatedly changed as a result of the peace settlements after the Napoleonic Wars, World War I and then World War II, and as a result of the collapse of the Soviet Union and Yugoslavia. For example, after World War I, Finland became independent from Russia which had taken it from Sweden in the early 19th century. So did the Baltic countries until they were reconquered by the Soviet Union in 1940. The end of World War I provoked the end of the Habsburg and Ottoman Empires, which resulted in a range of newly independent states in Central-eastern and South-eastern Europe, such as Czechoslovakia, Hungary, Yugoslavia and Albania. After World War II, Germany was first split up and then re-united in 1990. This coincided with the dissolution of the Soviet Union which also saw many new countries in Eastern Europe become independent.

The net effect of these and other changes has been a substantial rise in the number of independent states. Recently, this fragmentation was partly balanced by a slow process of European integration within an expanding European Union that - at the moment of writing (2019) - has 28 member states. Over time, the European Union has played an increasingly important role in population health, for example by regulating the emission of air-pollutants,

32 General histories of Europe emphasizing the emergence of the modern state are John M. Roberts, The Penguin History of Europe (London etc.: Penguin, 1996), esp. Book 3, and Timothy C.W. Blanning, The Pursuit of Glory: Europe, 1648-1815 (London: Allen Lane, 2007), Part 2. A distinction can be made between the advent of the modern state (a process starting in the Middle Ages and culminating in the absolutism of the 18th century), the rise of the concept of the 'nation' (i.e., a community founded on national awareness an idea that gained popularity in the 19th century), and the merging of the two in modern 'nation-states' (which most European countries had achieved by the middle of the 2oth century); see Hagen Schulze, States, Nations and Nationalism (Oxford: Blackwell, 1996). For a comparative history of the role of the state in dealing with infectious diseases in Britain, France, Germany and Sweden, see Peter Baldwin, Contagion and the State in Europe, 1830-1930 (Cambridge: Cambridge University Press, 1999). The creation of public health and health care systems reciprocally reinforced the process of state formation; see Abram de Swaan, In Care of the State (New York etc. : Oxford University Press, 1988). 
harmonizing tobacco control policies, and stimulating road traffic safety programs. ${ }^{33}$

These changes - dissolutions and mergers of political entities - provide interesting opportunities for studying the effect of political conditions on population health. In general, dissolution of a political entity has often increased disparities in life expectancy between its newly independent parts, whereas unification has often reduced such disparities. This strongly supports the idea that states make a difference for the health of their populations.

Here are a few examples, some of which have been illustrated in Figure 7 . After independence from Russia, Finland's life expectancy moved away from Russia's, and gradually converged with Sweden's during the 2oth century. During the 1920s and 1930s, life expectancy in the newly independent Baltic republics followed a similar upward trend as Finland's, but after World War II their life expectancies followed the unfavourable trends in Russia. It was only after the breaking up of the Soviet Union that their life expectancies diverged again from Russia's. The peaceful splitting up of Czechoslovakia into a Czech and a Slovak Republic in 1993 was followed by a small but measurable divergence of their life expectancies. The merger between the German Democratic Republic and the German Federal Republic in 1991 was followed by a rapid and strong convergence. Also, Slovenia and Croatia have been part of the Habsburg Empire, benefiting from the empire's homogenizing policies in the areas of education and public health. They still have higher life expectancies than parts of former Yugoslavia which have been under Ottoman rule, such as Bosnia, Serbia and North Macedonia. ${ }^{34}$

33 From consisting of only six countries (Germany, France, Italy, Netherlands, Belgium, Luxembourg), the European Union has been enlarged in four waves: the 1970s (Denmark and United Kingdom), the 1980s (Spain, Portugal and Greece), the 199os (Finland, Sweden and Austria) and the 200os (Malta, Cyprus and many Central and Eastern European countries). The United Kingdom has in a referendum voted to leave, but at the moment of writing (Autumn 2019) it was still unclear when 'Brexit' would occur. For illustrations of the role of the EU in recent health improvements, see Johan P. Mackenbach and Martin McKee, eds., Successes and Failures of Health Policy in Europe (Maidenhead: Open University Press, 2013), passim.

34 Many of these remarkable patterns of divergence and convergence were documented in Johan P. Mackenbach, "Political Conditions and Life Expectancy in Europe, 1900-2008," Social Science \& Medicine 82 (2013): 134-46. For an analysis of health convergence between East and West Germany, see Pavel Grigoriev and Markéta Pechholdová, "Health Convergence between East and West Germany as Reflected in Long-Term Cause-Specific Mortality Trends," European Journal of Population 33, no. 5 (2017): 701-31. The effect of the dissolution of Yugoslavia has been analysed in Stephen J. Kunitz, "The Making and Breaking of Yugoslavia and Its Impact on Health," American Journal of Public Health 94, no. 11 (2004): 1894-904. Although studies of the effect of becoming a member of the European 
Life expectancy at birth, men

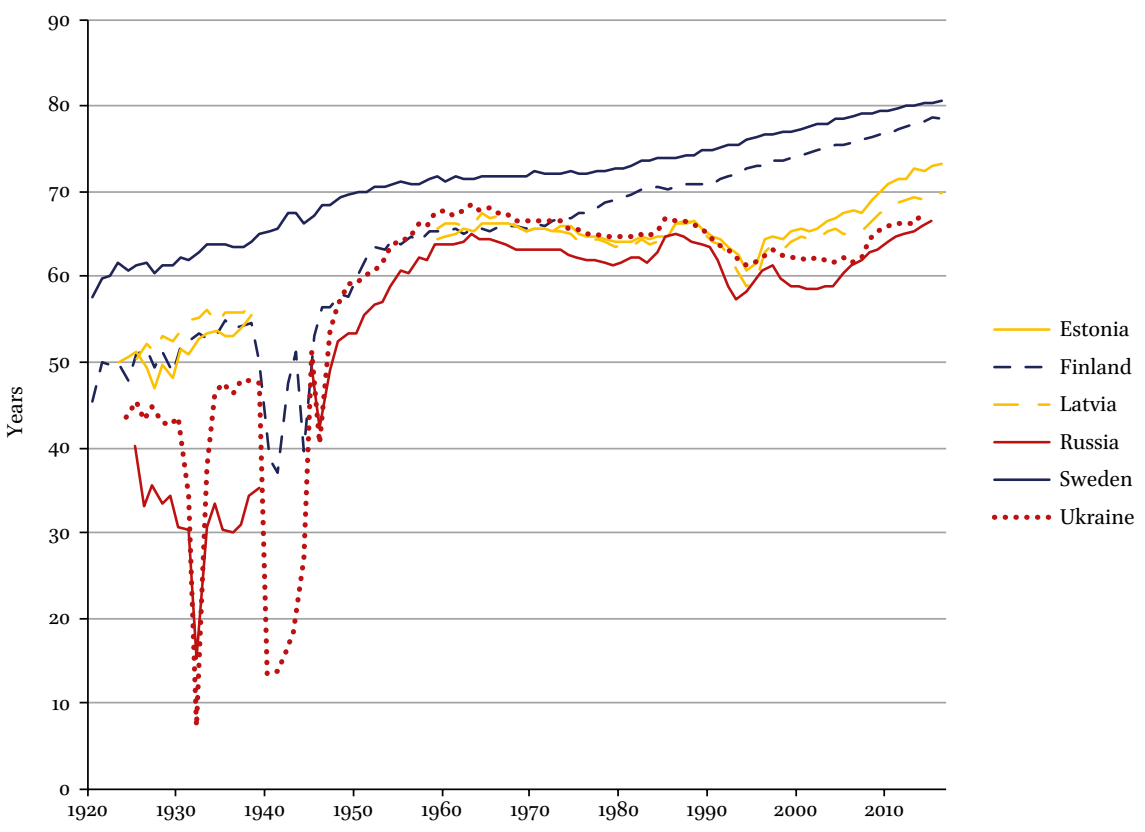

FIGURE 7 Trends in life expectancy in Northern and Eastern Europe, 1920-2015 SOURCE OF DATA: SEE SUPPL. TABLE 1

As in the case of economic growth, and despite being indispensable for population health improvement, the rise of the modern state undoubtedly also had darker sides. The nationalism underpinning the advent of modern 'nationstates' often fuelled mutual enmity, and the state has not merely become more effective in doing good things, but also in doing bad things. This does not only include warfare - already briefly mentioned above - but also colonization and exploitation of other parts of the world, and political oppression and even physical extermination of entire population groups. Sometimes, for example in the Soviet Union in the middle of the eth century, rapid population health improvements went hand-in-hand with brutal oppression of political opponents of the regime, making a balanced moral judgement nearly impossible (see Chapter 7 ).

Union have found no clear signs of life expectancy convergence following entry into the EU, as shown in Mackenbach, "Political Conditions and Life Expectancy" some convergence occurred before entry, probably as an effect of preparations for membership. 
A second political trend that has contributed to long-term improvements in population health is the rise of democracy and egalitarian ideologies. This has changed the way in which European countries govern their internal affairs, to the advantage of the majority of their populations. In the early 18th century, the political systems of European countries varied between republican democracy in Switzerland and full-blown autocratic monarchy in the Ottoman empire. Most European countries, including Russia, the Habsburg Empire, France, Spain and Sweden, still had absolutist monarchies, in which the ruler's will was supreme. Only a few countries, such as the Dutch Republic and Venice, tended towards early forms of democracy, based on a contract with a ruler-elect and rule by code of law (constitutional government). In the United Kingdom, England's Glorious Revolution (1688) had also left a form of constitutional monarchy. ${ }^{35}$

The 19th and 2oth centuries witnessed a gradual rise of liberal democracy. This is defined by representative government operating through law, by regular, free and fair elections based on universal suffrage, and by respect for individual rights including freedom of expression and association. Recurring revolts and revolutions often included a demand for more democracy, and because these demands were ultimately effective, many countries in Northwestern Europe developed into liberal democracies during the 19th century, to be followed by many countries in other parts of Europe in the early 2oth century. However, during the 2oth century many European countries also had shorter or longer periods of autocratic government, either communist or noncommunist (often fascist in inspiration). This happened during the Interbellum and then again after World War II, when many countries in Central-eastern and South-eastern Europe were forced to adopt communist autocratic regimes, and several countries in Southern Europe temporarily had non-communist autocratic regimes. ${ }^{36}$

There is a large literature showing that democracy is good for people's health, although there are also many exceptions to the rule. (Think of Cuba and China, which despite being governed by autocratic regimes have made great advances in population health.) This is not only because democracy is associated with prosperity, but also because democratic governments have more incentives to commit themselves to population health improvement.

35 For an overview of the governance systems of European countries in the 18th century, see Norman Davies, Europe: A History (London: Pimlico, 1997), p. 1265.

36 The rise of democracy in Europe can be traced in general histories of Europe (such as Davies, Europe: A History,) and has been analysed in more detail in Luciano Canfora, Democracy in Europe (Oxford: Blackwell, 2006). 
They tend to make decisions in accordance with voters' interests, and thus are usually more actively engaged in promoting the public good than authoritarian governments. This advantage may be strengthened by greater public accountability, greater inclination towards redistributive policies, and greater ability to recruit competent and honest people. ${ }^{37}$

The historical record in Europe shows that, during most of the 2oth century, democratically governed countries indeed had higher life expectancies than autocratically governed countries. Despite strong changes in cause-of-death patterns, this positive association has attenuated only slightly over time, and was still clearly present in 2010. In 1930, democratically governed countries had lower infant mortality and mortality from infectious and respiratory diseases, whereas in 1990 democratically governed countries had lower mortality from cardiovascular diseases and injuries. ${ }^{38}$

Although this supports the idea that democracy is good for population health, many other factors may confound this relationship, and longitudinal analyses actually suggest a more complex story, because increases in life expectancy were not always larger in democratically governed countries. On the contrary, the reverse applied in the period 1930-1960, when increases in life expectancy were larger in autocratically governed countries. As we will see later, the catch-up movement of countries in the South and East was actively managed by their autocratic non-communist regimes (as in the case of Spain and Portugal) and by their autocratic communist regimes. No other European country has experienced such a rapid growth of life expectancy as Russia did during the 1940s: 18 years gain in life expectancy in little more than a decade. Large gains in life expectancy were also seen in other Soviet republics, as well

37 See, for example, Jeroen Klomp and Jakob de Haan, "Is the Political System Really Related to Health?," Social Science and Medicine 69, no. 1 (2009): 36-46; Timothy Besley and Masayuki Kudamatsu, "Health and Democracy," Political Economy 96, no. 2 (2006): 313-18; Johan P. Mackenbach, Yannan Hu, and Caspar W.N. Looman, "Democratization and Life Expectancy in Europe, 1960-2008," Social Science \& Medicine 93 (2013): 166-75. On the counterexamples of Cuba and China, see Vicente Navarro, "Has Socialism Failed? An Analysis of Health Indicators under Socialism," International Journal of Health Services 22, no. 4 (1992): 583-6o1.

38 For the correlations between levels of democracy and life expectancy, see Suppl. Table 3. These correlations were statistically significant and positive in 1930-34, 1960-64, 1990-94, and 2010-14, and non-significant in 1870-74 and 1900-04. After adjustment for other determinants, statistically significant associations are mainly found in 2010-14, suggesting that in earlier periods confounding by other factors probably contributed to the positive association. 
as in Central-eastern and South-eastern European countries under Soviet influence. ${ }^{39}$

In the second half of the 2oth century, two waves of political reform brought full democracy to Spain, Portugal and Greece in the 1970s, and various degrees of democracy to the countries of Central-Eastern, South-eastern and Eastern Europe in the 1990s. Whereas the first wave was associated with a slight acceleration of the increase in life expectancy in the countries involved, the second wave had mixed effects, probably because too many changes occurred simultaneously. Planned economies were replaced by market economies, and painful economic adaptations were undertaken. As a result of these disruptive changes, life expectancy went down in many countries. However, some countries emerged quickly from this painful phase with a renewed increase of life expectancy, often in tandem with a rapid development towards full democracy. This mainly applies to the Baltic countries and countries in Central-eastern Europe that rapidly linked up with Western Europe. ${ }^{40}$

The rise of democracy would not have occurred without the rise of egalitarian ideologies, emphasizing the equality of all citizens, and this egalitarian ethos has undoubtedly also contributed to long-term improvements in population health. Reducing social inequality in all spheres of life, including income, wealth, access to education, and access to health care, has been a core policy focus for left-wing parties throughout the 2oth century. Despite all their failures, when they were in government these parties often at least partly achieved their egalitarian policy goals. When they were not in power the threat of a socialist or communist victory in democratic elections often stimulated other political parties to also embrace redistributive policies, and to support the development of the modern welfare state. This welfare state provided a safety net against poverty, and increased access to education and health care. ${ }^{41}$

39 For the correlations between levels of democracy at the beginning of each period, and changes in life expectancy during each period, see Suppl. Table 3. These correlations were statistically significant and negative in 1930-1960, and mostly non-significant in other periods. On the improvements in population health in Spain under the Franco regime, see Jose A. Tapia Granados, "Politics and Health in Eight European Countries," Social Science \& Medicine 71, no. 5 (2010): 841-50.

40 The impact of both waves of democratization on life expectancy and cause-specific mortality in Europe has been analysed in Mackenbach et al., "Democratization."

41 On the history and achievements of the welfare state, see, e.g., Evelyne Huber and John D. Stephens, Development and Crisis of the Welfare State (Chicago: University of Chicago Press, 2001). 


\section{Sociocultural History: the Lights Go On}

Over the past three centuries, important sociocultural changes have occurred as well. However, it is more difficult to capture these in quantitative indicators than in the case of economic or even political changes. Thanks to the development of modern survey methods we know quite a lot about current differences between European countries in, e.g., social cohesion, religiousness, and health literacy. Yet, trends in these and other factors can only be measured over relatively short time-periods. Nevertheless, three sociocultural conditions stand out as having had a profound impact on secular changes in population health: long-standing cultural differences between European countries; the 'civilizing process'; and increasing levels of literacy and other indicators of a more 'enlightened' way of life.

Despite a long-term tendency towards convergence, cultural differences between European countries have persisted until the present day. Studies have pointed to an important 'cultural fault-line' that runs along a North-South axis through the middle of Europe, and separates Western Christianity from Eastern Orthodox Christianity. In the West, a further distinction can be made between North-western Europe, which became mainly Protestant in the 16th and 17th centuries, and Southern Europe which remained Roman-catholic. These three 'cultural zones' can still clearly be distinguished, partly because their cultures have resulted in different economic, sociocultural and political trajectories. In the West, the historical sequence of medieval Humanism, Renaissance, Reformation/Counter-Reformation and Enlightenment resulted in - to mention a few of the important differences with the Eastern Orthodox zone individualization, secularization, early advances in science, early industrialization, separation between church and state, and early democratization. ${ }^{42}$

In these developments, which ultimately resulted in the 'rise of the West' as a global power, the Protestant countries in North-western Europe took the lead, and were followed by the Roman-catholic South and later still by the Eastern Orthodox East. Although it is unlikely that religious affiliation is the only cause of these different trajectories, there may be some truth in Max Weber's

42 For 'global cultural zones', see Samuel P. Huntington, The Clash of Civilizations and the Remaking of World Order (New York etc.: Simon \& Schuster, 1996). Cultural values (such as Ronald Inglehart's post-materialism values, and Welzel's emancipatory values) cluster geographically according to Huntington's cultural zones; see Ronald Inglehart and Wayne E. Baker, "Modernization, Cultural Change, and the Persistence of Traditional Values," American Sociological Review 65, no. 1 (2000): 19-51; Christian Welzel, Freedom Rising (Cambridge etc.: Cambridge University Press, 2013). 
thesis that modern capitalism could thrive in North-western Europe because of the 'protestant ethic' of hard work and savings. ${ }^{43}$

Protestantism is also associated with early improvements in population health. Traditionally-protestant countries always had a higher life expectancy, but the association was strongest in 1870, 1900 and 1930, and has gradually weakened in more recent times. This association is probably due - at least partly - to an effect of average levels of education on life expectancy. Protestantism and education are closely linked: because of the core Protestant idea that every church member should be able to read the Bible, levels of education have for a long time been higher in Protestant than in Roman-catholic and Eastern Orthodox countries. ${ }^{44}$

Religious affiliation is not the only cultural factor with long-standing differences between European countries. 'Cultural values', i.e., broad preferences that the members of a society share, also differ within Europe in rather stable patterns. For example, 'self-expression values' and 'emancipative values' are particularly prevalent in North-western Europe. Although data on long-term trends in these cultural values are not available, it is likely that these have evolved over time, from the more traditional values still prevalent in other parts of Europe. Such cultural changes may have reinforced a shift towards more rational behaviour with a focus on personal well-being, including good health. ${ }^{45}$

43 For some further comments on "the rise of the West," see Chapter 7. Max Weber's study of how the Protestant outlook on life may have contributed to the early rise of capitalism in North-western Europe is a classic of sociology (Max Weber, Die Protestantische Ethik Und Der Geist Des Kapitalismus (Bd. xx \& xxi: Archiv fur Soxialwissenschaft und Sozialpolitik, 1904-05)). However, the empirical evidence for this theory is mixed (Harold B. Jones, "The Protestant Ethic: Weber's Model and the Empirical Literature," Human Relations 50, no. 7 (1997): 757-78).

44 For the correlations between Protestantism and life expectancy, see Suppl. Table 3 . These correlations were statistically significant and positive in all periods. However, after adjustment for other determinants, statistically significant and positive associations are only found in 1870, 1900 and 1930, suggesting that the effect of Protestantism has become weaker over time. Within countries with mixed populations, such as the Netherlands and Switzerland, Protestants have long had higher life expectancies than Roman-Catholics; see, e.g., Judith H. Wolleswinkel-van den Bosch et al., "Determinants of Infant and Early Childhood Mortality Levels and Their Decline in the Netherlands," International Journal of Epidemiology 29, no. 6 (2000): 1031-40. These differences have recently faded; see Johan P. Mackenbach, "Jean Calvin, Calvinism, and Population Health: Impressions from Switzerland," European Journal of Public Health 17, no. 1 (2007): 1.

45 European countries' 'cultural values' can be found in, e.g., Welzel, Freedom Rising; Ronald Inglehart, Modernization and Postmodernization (Princeton: Princeton University Press, 
Another sociocultural trend which has probably contributed to long-term changes in population health is the 'civilizing process'. This is a general change in manners since the Middle Ages that has been described and analysed by German-British sociologist Norbert Elias (1897-1990). Using 'etiquette' books and other historical sources, Elias traced how behavioural norms with regard to violence, sexual behaviour, bodily functions, and table manners were gradually transformed. These changes did not primarily occur for health-related reasons, but because of increasing thresholds of shame and repugnance. For example, eating with one's hands from a common bowl became repulsive and was gradually replaced by eating with a fork from a private plate, long before people became aware of the risks of infection. ${ }^{46}$

This 'civilizing process', with its increasing 'self-restraint', formalization of manners, and repression of emotions, probably had a wide range of effects on population health. Increased sensitivity to bodily contact and to the smells and excretions of the human body may have contributed to the diffusion of hygienic practices, and thus to a decreasing risk of attracting infectious disease. As we will see in Chapter 6, stricter aggression regulation contributed to the decline of homicide. Conceivably, increased sexual restraint facilitated the adoption of fertility control and the decline of syphilis. More generally, increased 'self-restraint' probably facilitated many changes in health-related behaviours. ${ }^{47}$

Although these changes were partly autonomous, they were not completely independent from other societal changes. According to Elias, the requirement of 'self-restraint' originated in the growing interdependency of people, as a result of increasing integration into larger political and economic units. This happened earlier in North-western Europe than elsewhere, so that differences between European countries in this 'civilizing process' can plausibly have contributed to differences in the timing of several population health improvements.

However, the most important sociocultural change underpinning long-term population health improvement probably was a more rational attitude to

1997). For an empirical analysis of their health implications, see Johan P. Mackenbach, "Cultural Values and Population Health," Health \& Place 28 (2014): 116-32.

46 Norbert Elias, Uber den Prozess der Zivilisation (Basel: Verlag Haus zum Falken, 1939).

47 For an analysis of how the 'civilizing process' induced behavioural changes contributing to the decline of leprosy, plague, syphilis and cholera before the contagious nature of these diseases was known, see Johan Goudsblom, "Public Health and the Civilizing Process," Milbank Quarterly 64, no. 2 (1986): 161-88. For an application of Elias' theory to the development of public health, poverty relief, education, and social security, see Swaan, In Care of the State. 
health and disease. This was based on increased knowledge and diffused throughout the population by rising levels of literacy and education. These changes started as part of the broader 18th century movement of the 'Enlightenment', and continue until the present day. This is illustrated by the fact that adherence to health guidelines is still better among higher than among lower educated people. ${ }^{48}$

The 'Enlightenment' was the 18th century European movement advancing the idea that 'reason' is the primary basis of all knowledge. It aimed to emancipate human reason from prejudice, superstition and religious dogma, and its ideas and ideals penetrated many areas of life, from agriculture to politics, and from medicine to religion. The 'Enlightenment' started in Britain and the Dutch Republic, and rapidly spread from there to other countries in Northwestern Europe, including France and Sweden.

Here again, we find an example of where Protestantism (or factors underlying countries' choice for the Reformation) may have made a difference. Repression of Enlightenment ideas was more forceful in Roman-catholic countries, whereas in countries like Great Britain and the Dutch Republic which had adopted Protestantism, governments were more liberal-minded and populations were better educated. Enlightenment ideas were developed in academies, salons, and societies, and were diffused in the first newspapers and other periodicals for which literacy was of course an essential requirement. Consequently, ideals of educating the population led to more emphasis on schooling and, ultimately, compulsory education. ${ }^{49}$

This movement had important consequences for population health, through various pathways. A more rational approach to economic issues helped to start and sustain the agricultural and industrial revolutions. It stimulated the development of physics and other sciences. It led to a movement towards 'enlightened' government and, ultimately, democracy. It led to more rational forms of Christianity and, ultimately, to secularization, which removed some of the barriers to fertility control. It also sparked the rise of a more egalitarian ethos,

48 Studies found that rising the age of compulsory education led to better health behaviours (and lower mortality) in adulthood. For a review, see Mackenbach, Health Inequalities, Chapter 3 .

49 For a general overview of the Enlightenment and its spread in Europe, see Ulrich Im Hof, The Enlightenment: An Historical Introduction (Oxford: Blackwell, 1994). The development of the Enlightenment in Britain, and its impact on all aspects of life, have been detailed in Roy Porter, Enlightenment: Britain and the Creation of the Modern World (London: Allen Lane, 2000). For an enthusiastic review of the many contributions of the Enlightenment to human well-being, see Steven Pinker, Enlightenment Now (London: Allen Lane, 2018). 
which underlay the humanitarian reforms of the 18th and 19th centuries that were necessary for population-wide health improvement.

By fostering science and a more rational approach to disease it also stimulated medical science and the adoption of new scientific insights by medical practitioners. In the general population, starting with the elites, new attitudes with regard to the care of the body emerged, with more attention to preventing disease. As part of this medical revolution, it also stimulated the development of personal and public hygiene. Even among the elites, regular washing of body and clothes only became habitual in the late 18th and early 19th centuries, partly because previous generations had mistakenly believed that contact with water increased the risk of illness. The sanitary reforms of the second half of the 19th and first half the 2oth century were accompanied by health education campaigns which contributed importantly to further changes in popular conceptions of disease and acceptance of modern hygienic insights. Pushed to the extremes, 'Enlightenment' thinking led to the previously unthinkable idea that perhaps, in the future,

the improvement of medical practice [...] will mean the end of infectious and hereditary diseases and illnesses brought on by climate, food or working conditions. It is reasonable to hope that all other diseases will likewise disappear as their distant causes are discovered. ${ }^{50}$

As a result of this movement, and the schooling program to which it led, levels of literacy and education rose tremendously in all European countries, but with important differences in timing between countries. Trends in levels of literacy are pictured in Figure 8. Literacy can be measured by the proportion of brides and bridegrooms (or other people who had to sign documents) who were able to sign their names. This can be traced over a much longer period than trends in levels of education. ${ }^{51}$

5o For a general overview of the changes in medical science and medical practice stimulated by the Enlightenment, see Roy Porter, The Greatest Benefit to Mankind (London: HarperCollins, 1997), Chapter X. The emergence of 'enlightened' attitudes towards the care of the body in France were traced in G. Vigarello, Histoire des Pratiques de Santé: Le Sain et le Malsain depuis le Moyen Âge (Paris: Éd. du Seuil, 1999). A study of changes in attitudes towards common infectious diseases in late 19th century London has documented the rise of modern hygienic practices under the influence of prevention campaigns; see Anne Hardy, The Epidemic Streets: Infectious Disease and the Rise of Preventive Medicine, 1856 1900 (Oxford etc.: Oxford University Press, 1993). The quote is from the Marquis de Condorcet (1743-1794), and is reproduced here from Porter, Greatest Benefit, pp. 245-46.

$5^{1}$ More recently other measures for literacy have been proposed, such as 'numeracy', indicated by the ability to give your exact age (Brian A'Hearn, Jörg Baten, and Dorothee 
Around 1800, countries in North-western Europe, such as Britain, Sweden and the Netherlands, had much higher levels of literacy than countries in Southern or Eastern Europe. This was the result of differences between countries in the promotion of literacy in previous centuries. The Swedish example is particularly striking: during the 17 th and 18 th centuries, massive campaigns were held to enforce a national law that required all parishioners to be able to read the Bible. The campaigns were based on home schooling, and included yearly examinations. A central register of parishioners' reading ability was kept, and shows a strong rise of reading ability in response to the campaigns.

During the 19th century, many other North-western European countries also achieved a rise in literacy, with countries in Southern and Eastern Europe often only catching up during the 2oth century. The steepest rises ever were seen in the Soviet Union and Albania, where intensive literacy campaigns in the 1930s, 1940 s and 1950s succeeded in rapidly eradicating illiteracy. Portugal stands out as a laggard in Southern Europe, with a proportion of literate people of only $80 \%$ as late as in 1975 . Largely similar trends are seen for average levels of education (see Suppl. Figure 7). ${ }^{52}$

Rising levels of literacy and education made important contributions to long-term population health improvements. This worked not only indirectly, e.g., via promoting economic development, but also more directly via promoting the adoption of health-conducive behaviours in the population. Individual-level evidence of the effects of literacy and levels of education on mortality in historical times indicates, that in the last decades of the 19th century infant mortality declined earlier among the babies of literate mothers. These were probably more able or willing than illiterate mothers to apply modern hygienic insights and to restrict fertility. As mentioned above, level of education has remained an important determinant of health until the present day, partly because of the greater 'health literacy' of higher educated people. ${ }^{53}$

Crayen, "Quantifying Quantitative Literacy: Age Heaping and the History of Human Capital," Journal of Economic History 69, no. 3 (2009): 783-808). Trends in numeracy generally mirror those for conventional measures of literacy (Dorothee Crayen and Joerg Baten, "Global Trends in Numeracy 1820-1949 and Its Implications for Long-Term Growth," Explorations in Economic History 47, no. 1 (2010): 82-99).

For the rise of schooling in Europe, see Robert A. Houston, Literacy in Early Modern Europe (Edinburgh etc.: Pearson Education Limited, 2002). For the Swedish experience, see Egil Johansson, The History of Literacy in Sweden: In Comparison with Some Other Countries, vol. 12, Educational Reports Umeå, (Umeå: Umeå universitet, 1977). The rise in literacy during the 19th century was largely due to voluntary schooling, and often preceded the introduction of compulsory schooling.

53 Protective effects of mothers' literacy on infant mortality in the later 19th century have been found in the Netherlands (O.W.A. Boonstra, De Waardij van eene Vroege Opleiding 


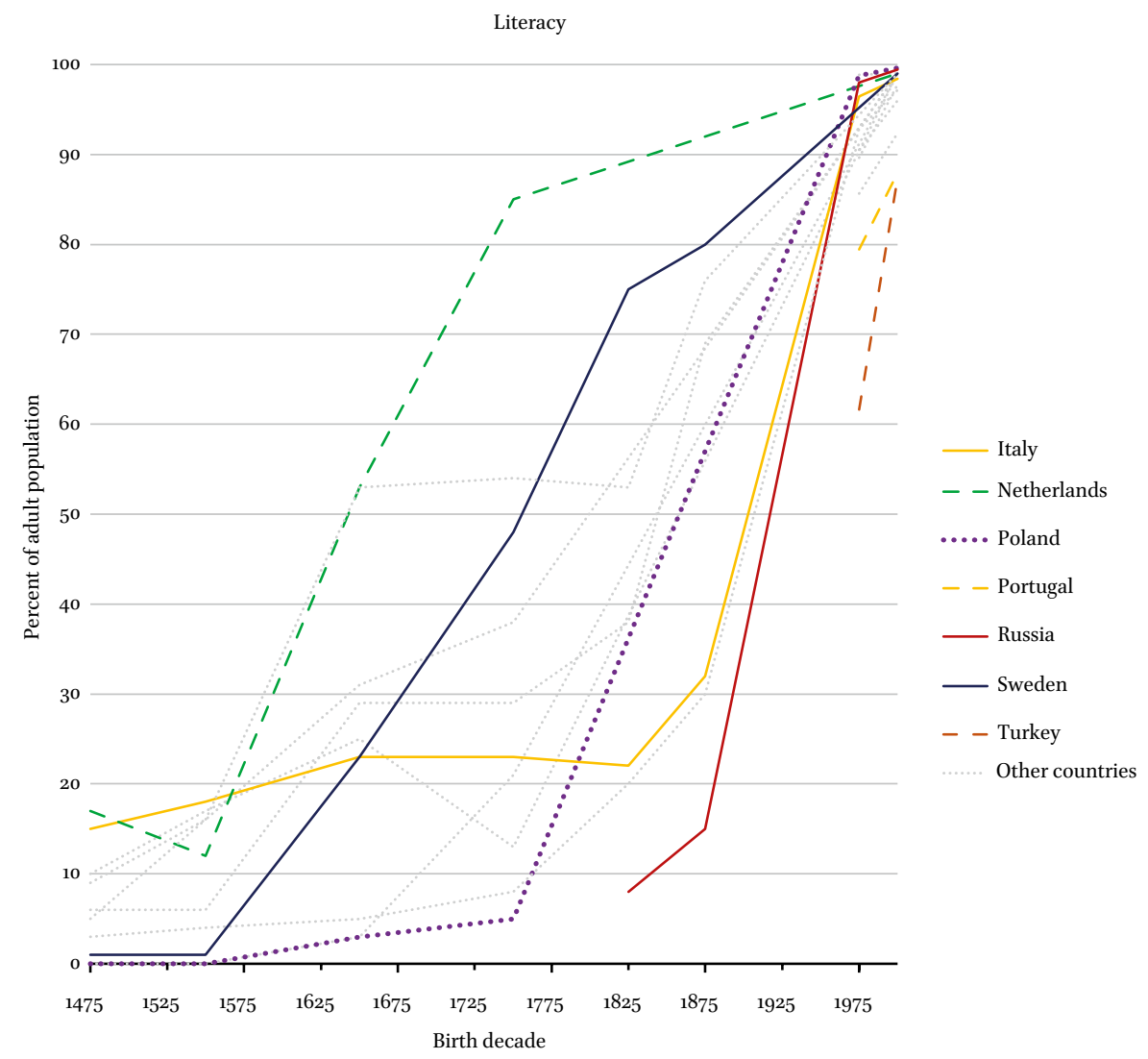

FIGURE 8 Trends in literacy in Europe, $1475^{-2000}$ SOURCE OF DATA: WWW.OURWORLDINDATA.ORG (ACCESSED 01/08/2019)

Before national income became an important determinant of life expectancy, a country's average level of education was strongly positively associated with life expectancy. This was the case in 1870,1900 and 1930, and was due to the fact that countries with a higher average level of education had lower infant mortality and lower mortality from infectious and respiratory diseases. However,

(Wageningen: Wageningen University, 1993), Chapter 9), England and Wales (Woods, Demography, Chapter 7), and the US (Samuel H. Preston and Michael R. Haines, Fatal Years (Princeton: Princeton University Press, 1991), Chapter 4). For a recent study of 'health literacy', see Kristine Sørensen et al., "Health Literacy in Europe: Comparative Results of the European Health Literacy Survey (HLS-EU)," European Journal of Public Health 25, no. 6 (2015): $1053-58$. 
the strength of this association gradually diminished over time, perhaps because of converging levels of education between countries. ${ }^{54}$

Having come at the end of this rather optimistic account of the many benefits of the Enlightenment, it is time to ask ourselves - like we did in the case of economic and political change - whether there was (or is) a darker side as well. This is a difficult question that - if addressed seriously - would bring us into deep philosophical waters. Let me just mention, therefore, that the 'Enlightenment project' has been criticized on several grounds. One is its emphasis on the autonomy of the individual, which may have contributed to a loosening of social cohesion and mutual responsibility. Another is that the use of reason for instrumental purposes, i.e., as a means to whatever end we choose to pursue, may have fuelled our will to domination over others and the natural world, thereby contributing to the rise of totalitarian regimes and environmental destruction. We will briefly come back to this 'dialectic of the Enlightenment' in Chapter 8.55

\section{Public Health and Medical Care}

\section{A Short History of Public Health}

Tracing the history of 'public health' over three centuries, during which its name has changed several times, is not easy. The problem is aggravated by differences in national language which make it difficult to recognize 'public health' (or the concepts, professions and institutions hiding behind other English terms) in other European countries. It is only recently that the un-translated term 'public health' has come into use throughout Europe - indicating a certain degree of European convergence. ${ }^{56}$

54 For the correlations between average years of education and life expectancy, see Suppl. Table 3 . These correlations were statistically significant and positive in $1870-74$, 19001904, 1930-34, and 1960-64, and non-significant in 1990-94 and 2010-14. The correlations between changes-over-time in education and changes-over-time in life expectancy can be found in the same table.

55 For a summary of the most common critiques of the Enlightenment, see James Schmidt, "What Enlightenment Project?," Political Theory 28, no. 6 (2000): 734-57. "Dialektik der Aufklärung" is the title of a famous book by German philosophers Horkheimer and Adorno, who saw the seeds of Nazi totalitarianism in the 'instrumental reason' promoted by the Enlightenment (Max Horkheimer and Theodor W. Adorno, Dialektik der Aufklärung (Amsterdam: Querido, 1947)).

$5^{6}$ For a comparison of current terminology in eight European languages, see Sanja Kaiser and Johan P. Mackenbach, "Public Health in Eight European Countries: An International Comparison of Terminology," Public Health 122, no. 2 (2008): 211-16. The European Public 
A common definition of 'public health' is: "the art and science of preventing disease, prolonging life and promoting health through the organized efforts of society." This emphasizes the collective nature of public health interventions, as distinct from the individualized nature of medical interventions. If we take this as our definition, we can roughly divide the history of the field in four phases. These are each characterized by a different name: 'medical police' (18th century), 'public hygiene' (19th century), 'social hygiene' (first half of 2oth century), and 'new public health' (second half of the 2oth century). ${ }^{57}$

'Social medicine' is another frequently used term, both in the past and today, but it has developed too many different meanings to be useful for this overview. These range from an almost-synonym with 'public health' (in continental Europe in the 19th century), to the branch of medicine involved in 'state medicine' (e.g., medical assessments for social insurance benefits, in continental Europe in the 2oth century), to a socially critical approach to population health issues (in Britain in the middle of the 2oth century, and in Latin America until the present day). ${ }^{58}$

The field of 'public health' did of course not come out of the blue. It built on earlier approaches, such as the precepts for individual hygiene that had been practiced in Greek and Roman times. It also built on the idea that governments had a certain responsibility for the health of their citizens which already came up in the Middle Ages, e.g. with respect to quarantine measures against epidemic diseases. However, after 1700 it gradually developed an identity, widened its scope to cover all population health issues, and built a growing body of empirically based knowledge as well as dedicated institutions and a dedicated profession. ${ }^{59}$

Health Association, founded in 1992, brings together 41 national associations of public health.

The definition of 'public health' given in the text is from Acheson (Department of Health, Public Health in England (the Acheson Report) (London: Her Majesty's Stationery Office, 1988)). The proposed division in four phases is schematic, and in reality many other terms have been used as well, both in Britain and in other European countries. For example, the term 'public hygiene' has not been regularly used in Britain (where, in the 19th century, the term 'public health' was coined instead), and for some time in the 1970s Britain referred to the field as 'community medicine' before returning to the classical term 'public health'.

$5^{8}$ See, e.g., Porter, Health Citizenship; George Rosen, "What Is Social Medicine?," Bulletin of the History of Medicine 21, no. 5 (1947): 674-733.

59 Rosen, History. A comparative history of public health in Europe is not available; closest comes Porter, The History of Public Health and the Modern State which contains essays on France, Germany, Great Britain, Sweden and Russia. Porter, Health, Civilization and the State has a deeper analysis of the connections between the rise of the modern state and the development of public health, as does Baldwin, Contagion and the State in Europe. 
This started in the 18th century which saw the emergence of an approach called 'medical police'. This term often confuses modern readers, but it refers to the creation of a systematic 'medical policy' by governments, and to its implementation through administrative regulations such as laws, taxes and inspections. It fitted in a more general movement to increase the role of the state in economic and demographic affairs in order to maximize its power ('mercantilism'), which was important in these times of inter-European competition. The development of 'medical police' culminated in the work of Johann Peter Frank (1745-1821), a German physician who held positions throughout Europe (Saxony, Lombardy, Austria, Russia) and who published his System einer Vollständigen Medicinischen Polizey between 1779 and 1819.

This was a work in six parts that became highly influential, as illustrated by the fact that it was translated into many languages. It described in detail how the state could promote the health of its inhabitants and the size of its population, systematizing the available arsenal of collective measures to improve population health. This arsenal was - of course - based on contemporary insights into the causes of disease. In the 18th century, many new insights had been gathered thanks to the revival of Hippocratic or 'ecological' theories of disease, for example by the extensive use of geographical comparisons ('medical geography'). Frank's six-volume compendium contained detailed guidance with regard to the care of pregnant women, infants and children, accident prevention, the hygiene of food and housing, sanitation, and many other topics. ${ }^{60}$

Frank's thinking fitted better in the autocratic political regimes of the German states and the Habsburg Empire than in the more liberal regimes of Britain and the Dutch Republic, and even in the German-speaking parts of Europe his ideas were not widely implemented. Together with the political ideal of 'enlightened despotism', the concept of 'medical police' generally went outof-fashion in the first decades of the 19th century. Nevertheless, the insights

6o Medical historian George Rosen (1910-1977) published several papers on Frank's life and works (George Rosen, "Biography of Dr. Johann Peter Frank Written by Himself," Journal of the History of Medicine and Allied Sciences 3, no. 2 (1948): 279-314), the origins of his ideas (George Rosen, "Cameralism and the Concept of Medical Police," Bulletin of the History of Medicine 27 (1953): 21-42), and the reception of the concept of 'medical police' in Europe (George Rosen, "The Fate of the Concept of Medical Police 1780-189o," Centaurus 5, no. 2 (1957): 97-113). Frank also authored "The People's Misery: Mother of Diseases," probably the first systematic exposition of the relationship between poverty and disease (1790); see Henry E. Sigerist, "Frank, Johann Peter. The People's Misery: Mother of Diseases," Bulletin of the History of Medicine 9 (1941): 81-100. 
and interventions systematized by Frank were, to varying degrees, applied in many European countries.

In what has been called "the eighteenth century campaign to avoid disease," many environmental measures were taken which may have reduced disease. Measures were taken to drain low-lying, swampy areas, because standing water had been recognized as a source of disease. Measures were taken to flush away the filth from urban areas, because filth did not only stink, but was also suspected to cause disease. Measures were taken to improve the ventilation of closed areas such as houses, ships and prisons, because odours were another suspected cause of disease. Measures were taken to re-inter corpses from inside churches and built-up areas to cemeteries and places outside cities, where they could no longer spread disease. Measures that had already proven their effectiveness in earlier centuries, such as cordons sanitaires and quarantine of ships, were also strengthened in this period of 'medical police'. Although these ideas spread throughout Europe, we can safely assume that there were huge differences between European countries in the adoption of these measures. ${ }^{61}$

The 'public hygiene' that emerged at the beginning of the 19th century represented a new twist in the collective approach to health problems. It was, on the one hand, encouraged by the emergence of new health problems, and, on the other hand, inspired by an increased understanding of the causes of disease. Industrialization and urbanization were accompanied by a worrying rise of infectious disease mortality. The arrival of cholera epidemics in the $1830 \mathrm{~s}$ and 1840 s, in particular, acted as a strong catalyst for developing a more effective approach to avoid disease. At the same time, scientific advances made it possible to more precisely pin-point the environmental conditions causing disease, and - equally importantly - increased people's confidence that disease and mortality could be fought with rationally designed measures. ${ }^{62}$

Initially this was no more than an intuition, as is evident from the Encyclopédie ou Dictionnaire Raisonné des Sciences, des Arts et des Métiers by Diderot and d'Alembert, published in the last decades of the 18th century (Plate 4). This

61 "The eighteenth century campaign to avoid disease" is the title of a book by James Riley (Riley, Campaign). That such a campaign did really exist is also clear from 18th century attempts to make London a healthier place (Roy Porter, "Cleaning up the Great Wen: Public Health in Eighteenth-Century London," Medical History 35, no. S11 (1991): 61-75).

62 For an analysis of the treatment of hygiene in the Encyclopédie, see William Coleman, "Health and Hygiene in the Encyclopédie: A Medical Doctrine for the Bourgeoisie," Journal of the History of Medicine and Allied Sciences 29, no. 4 (1974): 399-421. Condorcet's statement, cited above, is another example of the naïve optimism about the possibilities to eliminate disease, which would, however, at least partly be justified by the developments in the following two centuries. 


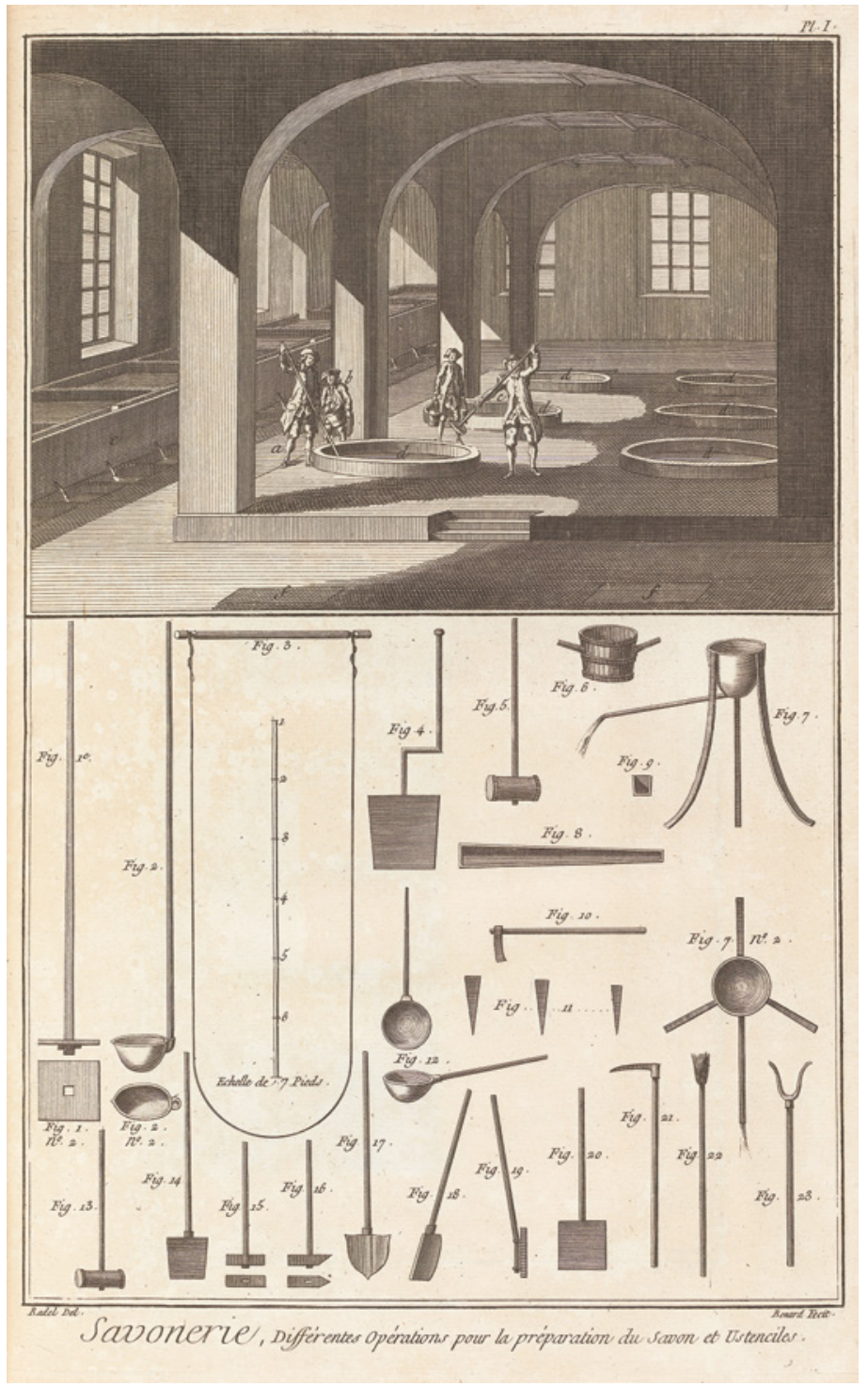

PLATE 4 Savonerie [Soap factory] as explained in the Encyclopédie, 1771

Detailed plates in Volume IX of the Encyclopédie ou dictionnaire raisonné des sciences, des arts et des métiers by Diderot and d'Alembert, which appeared in 1771, explain how soap can be made. In the 18th century, soap production was still artisanal and small-scale, and soap was expensive, partly because of a tax on soap levied by governments. Soap was not generally used for bathing until it was produced on an industrial scale in the second half of the 19th century.

COLLECTION KONINKLIJKE BIBLIOTHEEK, THE HAGUE. REPRODUCED WITH PERMISSION 
has an optimistic lemma on Hygiène arguing that prevention is more useful than treatment, and that for the maintenance of health 'only' three things are necessary: to keep the individual in a healthy situation, to remove all causes of disease, and to comply with all health precepts.

This 'public hygiene' movement originated in France after the Revolution of 1789, which created room for reforms of the health system that had been in debate for decades, and that now suddenly seemed practicable. For the first time in history, a 'right to health' of all citizens was agreed on in the Assemblée Constituante in 1790. Committees were installed to prepare a national program of medical assistance for the poor and a new public health system. However, before most of these proposals could be carried through, the revolution ended in chaos, dictatorship, the Napoleonic Wars, and lack of funds. ${ }^{63}$

Despite these negative immediate results, several of the ideas developed during the French revolution were revived in the following decades. For example, the proposal for a multidisciplinary health council (Conseil de Salubrité) was already implemented in Paris in 1802, and in other French cities and départements in the following decades. In the 1820 s and 1830 , the science of public hygiene developed in France under the intellectual leadership of people like Alexandre Parent-Duchâtelet (1790-1836) and Louis-René Villermé (17821863). In practical applications, however, France soon lagged behind other European countries, perhaps because of the conservative backlash after the violence of the Revolution and Napoleonic Wars. ${ }^{64}$

From France the 'public hygiene' movement spread to other European countries, and most importantly to England where it inspired Edwin Chadwick (1800-1890) to his 'sanitary idea' which would ultimately be adopted everywhere. This idea implied that the major health problems of the time had to be combated by a combination of safe disposal of faeces and provision of safe

63 The French revolution of 1789 was one of three European revolutions that acted as a catalyst for important changes in public health policy, the other two being the European revolutions of 1848, and the Russian revolution of 1917. The practical results were mixed, and only the Russian revolution resulted in rapid and radical changes to the health system, but at a very high price in personal freedom and human lives (see Chapter 7 ).

64 The leading role for France in the initial phase of 'public hygiene' is illustrated by the fact that the first ever professor in hygiene, Jean-Noël Hallé (1754-1822), was appointed at the Ecole de santé in Paris in 1794, that the first scientific journal in the field of public health, the Annales d'hygiène publique et de médecine légale was founded in France in 1829, and that the first scientific handbook on public hygiene was published in Paris in 1836; see Matthew Ramsey, "Public Health in France," in The History of Public Health and the Modern State, ed. D. Porter (Amsterdam: Editions Rodopi, 1994); Ann E.F. La Berge, Mission and Method (Cambridge etc.: Cambridge University Press, 2002). 
drinking water, and thus by connecting houses to sewerage systems and piped drinking water. ${ }^{65}$

With England as an intermediate station, public hygiene and the 'sanitary movement' then spread to many other European countries. There it was given similar names (sometimes retrospectively), such as Hygiénistes in France and Hygiënisten in the Netherlands. During the 19th century this movement gradually succeeded in implementing a range of sanitary reforms, not only in the area of faeces disposal and drinking water, but also in areas like housing conditions, working conditions, infant care, and child labour. Here again, there were huge differences between European countries in the speed of adoption of these measures, with North-western Europe being distinctly ahead of Southern and Eastern Europe. ${ }^{66}$

Some of the delays were due to political opposition from conservative and liberal circles, for example when taxes had to be raised to pay for investments in sanitation infrastructures, or when the need for government interventions in trade and industry clashed with laissez-faire economic policies. It is no surprise, therefore, that political conditions remained important for the development of 'public hygiene'. This is illustrated by the catalytic role of the widespread political unrest in 1848 , partly sparked by bad harvests and famine, of which the revolutions in Paris and Berlin are the most widely known. ${ }^{67}$

Most of the 1848 revolts and revolutions were repressed by military force, often with the backing of conservative sections of society, but they often did lead to some constitutional changes (e.g., to increase the number of people who had the right to vote in elections). They can also be seen as the birth-place of public health in many continental-European countries. For example, on 8 March 1848, in the middle of the revolution in Paris, orthopaedic surgeon and editor of the Gazette Médicale de Paris Jules Guérin (1801-1886) was the first to use the term médecine sociale in an editorial celebrating the revolution.

65 For the spread of ideas from France to England, see Erwin H. Ackerknecht, "Hygiene in France, 1815-1848," Bulletin of the History of Medicine 22 (1948): 117-55. For the early development of public health in Britain, see Christopher Hamlin, "Public Health in Great Britain," in The History of Public Health and the Modern State, ed. D. Porter (Amsterdam: Editions Rodopi, 1994).

66 Several national histories of 'public hygiene' are available, e.g. for Britain (Anthony S. Wohl, Endangered Lives (London etc.: Dent and Sons, 1983)), France (Jorland, Société), and the Netherlands (Eduard S. Houwaart, De Hygiënisten (Groningen: Historische Uitgeverij Groningen, 1991)). For the history of public hygiene in some other European countries, see Chapter 7 .

67 For political opposition to public health reforms, see, e.g., Christopher Hamlin and Pat Sidley, "Revolutions in Public Health: 1848, and 1998?," British Medical Journal 317, no. $715^{8}$ (1998): 587-91. 
Equally emblematic is the role of German pathologist Rudolf Virchow (1821-1902) during the revolution in Berlin. Earlier in 1848, Virchow had been sent on a mission to Upper Silesia to study the causes of a typhus epidemic. In his report, Virchow not only established the medical diagnosis of the disease, but related the epidemic to a famine resulting from crop failure in the previous years, whose effects were concentrated among poor Polish peasants. Virchow blamed the epidemic on the oppression of these peasants by the local German aristocracy, and his conclusion was that elimination of social inequality was the only way to prevent further typhus epidemics in the future.

On 19 March 1848, just after returning from his trip, and inflamed by the conclusions of his investigations, Virchow joined the revolution. He even defended a barricade using an old pistol borrowed from a medical colleague. During the rest of the year Virchow actively participated in the democratic, republican and socialist movements, and created a weekly journal called Die Medicinische Reform, in which he published many of his famous one-liners, including "Medicine is a social science, and politics nothing else than medicine at a larger scale." 68

During most of the 19th century, there was no consensus on whether or not some of the most prevalent diseases were contagious or not, and if so how diseases exactly spread from person to person. This did not always prevent the implementation of effective countermeasures - the non-contagionist 'miasma theory' prescribed the removal of rotting organic material, which accidentally also helped in reducing risks of infection. Nevertheless, lack of more precise knowledge certainly reduced their precision. It was only towards the very end of the 19th century that the role of micro-organisms in the causation of many diseases was definitively shown. ${ }^{69}$

This 'bacteriological revolution' did not only help to more precisely target sanitation measures, but also opened up a whole arsenal of other interventions. These included antitoxins (which reduced mortality from diphtheria), antisepsis and asepsis (which made surgery and childbirth safer), and isolation of patients known to be infective (which reduced transmission of tuberculosis

68 Literally: "Die Medizin ist eine soziale Wissenschaft, und die Politik ist weiter nichts als Medizin im Großen." For a more extensive analysis of the link between the revolutions of 1848 and the development of public health, see Johan P. Mackenbach, "Politics Is Nothing but Medicine at a Larger Scale: Reflections on Public Health's Biggest Idea," Journal of Epidemiology \& Community Health 63, no. 3 (2009): 181-84.

69 The difficulty of getting contagionist ideas accepted was partly due to opposition from economic interests, which feared that trade would be harmed by quarantine and other measures to stop contagion; see Erwin H. Ackerknecht, "Anticontagionism between 1821 and 1867," Bulletin of the History of Medicine 22 (1948): 562-93. 
and other contagious diseases). Due to the triumphs of bacteriology, traditional 'public hygiene' suddenly seemed to be based on false premises. However, the application of bacteriological insights to the solution of many population health problems still required collective interventions, such as pasteurization of milk, inspection of food products, and screening for tuberculosis. ${ }^{70}$

Although the collectivist approach of 'public hygiene' could easily be adapted to carry out some of these new measures, other measures required a new, more personal approach. In the first decades of the 2oth century, this new approach emerged in the form of 'social hygiene'. This involved the development of preventive programs for vulnerable groups: pregnant women and newborns (antenatal and perinatal care), children (consultation clinics for infants and toddlers, school health care), workers (occupational health care), and sufferers from certain infectious diseases and their contacts (consultation clinics for tuberculosis and venereal diseases).

For all these groups, effective prevention depended on the successful merging of bacteriological and other scientific insights with an understanding of the social determinants of disease. Social hygiene also became involved with another rapidly growing area of collective interference with population health, namely social security, as many European countries developed their first schemes of protection against loss of income in the event of accident, illness, and unemployment.

In the development of social hygiene, which went hand in hand with the first steps towards a welfare state, Germany took the lead, as illustrated by the international influence of Alfred Grotjahn (1869-1931). In Grotjahn's conception, social hygiene should focus on influencing social conditions in order to combat contagion, poor nutrition and other specific risk factors of disease. Consultation clinics, in which clients were called up for regular visits with a doctor or nurse, and district nurses, who brought modern hygienic and dietary practices into many people's homes, were the characteristic way of working in this new approach. These ideas diffused throughout continental Europe, including the early Soviet Union where Nicolai Semashko (1874-1949) established a system of primary care based on the principles of social hygiene. ${ }^{71}$

70 See Rosen, History, Chapter viI. For how the 'bacteriological revolution' changed the practice of public health, see David S. Barnes, The Great Stink of Paris and the NineteenthCentury Struggle against Filth and Germs (Baltimore: Johns Hopkins University Press, 2006).

71 For an analysis of the rise of social hygiene within wider concerns with the "quality of population," see Porter, Health, Civilization and the State, Chapter 10. On the role of Grotjahn in developing social hygiene, see S. Milton Rabson, "Alfred Grotjahn, Founder of Social Hygiene," Bulletin of the New York Academy of Medicine 12, no. 2 (1936): 43-58. 
The Interbellum, the period in which social hygiene blossomed all over Europe, also witnessed two new phenomena which both had a profound impact on the development of public health: eugenics and international health action. After World War I, health was a central concern of many European nations. This was not only because it was important to recover from heavy population losses, but also because collective actions for health were a natural way to unite their populations. Some of these had been brought together in newly formed countries, whereas other populations were sharply divided between left-wing and right-wing political ideologies. ${ }^{72}$

Whereas one important strand of social hygiene stressed the importance of environmental factors, another strand emphasized the role of genetics. This competing strand, 'eugenics', believed that improvements in environmental conditions could only lead to degeneration of the population, because they would promote the survival of genetically weaker individuals. It propagated selective reproduction instead - an idea that came in many gradations, ranging from relatively benign to outright malicious. When it combined with feelings of national or racial superiority, eugenics could derail into 'racial hygiene', as in the case of Nazi Germany where these ideas were taken to the extremes and led to the genocide of 6 million Jews. Because of these and other criminal applications, we tend to forget that 'eugenics' in milder forms was popular throughout Europe. ${ }^{73}$

A second important development of the interwar period is the rise of international organizations in public health. International cooperation in public health had started in the 19th century, with international sanitary conferences in which European countries tried to reach an agreement on stemming the spread of infectious diseases across national borders. However, after World War I, a step-change occurred with the creation in 1920 of the League of

$7^{2}$ This was a fascinating period beset with contradictions and ambivalences. For the connections between state building and social hygiene in newly formed states such as Czechoslovakia and Yugoslavia, see Iris Borowy and Wolf Gruner, eds., Facing Illness in Troubled Times (Frankfurt am Main: Peter Lang, 2005), various chapters.

73 Eugenics built on the growing understanding of genetics, for which the basis had been laid by Gregor Mendel (1822-1884). For an in-depth analysis of Nazi health policies, and the connections between German social hygiene and genocide, see Paul Weindling, Health, Race and German Politics between National Unification and Nazism, 1870-1945 (Cambridge etc.: Cambridge University Press, 1993); Paul Weindling, Epidemics and Genocide in Eastern Europe, 1890-1945 (Oxford etc.: Oxford University Press, 2000). Sweden had a program of compulsory sterilization of people with mental illness or an antisocial lifestyle. These and more benign applications of 'eugenics' were all part of the same 'social hygiene' movement which easily combined with authoritarianism; see Mark Mazower, Dark Continent (London: Allen Lane, 1998), Chapter 3. 
Nations Health Organization (LNHO), the precursor of the current World Health Organization (wHO). Apart from producing statistical overviews and acting as a platform for exchanging information and expertise, the LNHO also engaged in several field studies of post-war outbreaks of infectious diseases in Europe, such as typhus and malaria, with keen attention to the social determinants of disease. ${ }^{74}$

In these activities the LNHO was supported by the International Health Division of the Rockefeller Foundation, a philanthropic organization that became strongly engaged in public health work in the interwar period in Europe (and elsewhere in the world). Whereas the LHNO was a (politically and financially) weak organization, the Rockefeller Foundation was rich and competent, and made important contributions to population health improvement, particularly in Southern Europe. By providing expertise and financial support, the Rockefeller Foundation helped in tackling tuberculosis in France and malaria in many Southern European countries. It also helped to bring local expertise up-to-date by supporting the foundation of national schools of public health. Although politically independent, the Rockefeller Foundation worked within the foreign affairs policy goals of the United States. These included strengthening newly formed nations in Southern, Central-eastern and South-eastern Europe, and opposing the perceived threats of the communist Soviet Union. ${ }^{75}$

In the meantime, the arsenal of effective public health interventions had greatly expanded beyond what was available in the beginning of the 2oth century. Vaccinations had been developed against several infectious diseases, as had chemical methods for vector control, such as delousing by fumigation to prevent typhus, and destruction of larvae or mosquitoes by insecticide spraying to prevent malaria. Workplaces could be made safer by new methods of accident prevention and worker protection, and by the introduction of safer production methods. Nutrient-deficiency diseases like rickets, goitre and pellagra could be prevented by making sure that essential micro-nutrients were present in people's food.

74 On international sanitary conferences, see Mark Harrison, "Disease, Diplomacy and International Commerce," Journal of Global History 1, no. 2 (2006): 197-217. On the League of Nations Health Organization, see Patricia A. Sealey, "The League of Nations Health Organisation" (Doctor of Philosophy Ohio State University, 2011); Paul Weindling, ed., International Health Organisations and Movements, 1918-1939 (Cambridge etc.: Cambridge University Press, 1995).

75 For a history of the International Health Division of the Rockefeller Foundation, see John Farley, To Cast out Disease (Oxford etc.: Oxford University Press, 2004). Aspects of its history are also described in various chapters of Weindling, International Health Organizations. 
After World War II it soon became clear that old health problems were being replaced by new ones. Mortality and morbidity patterns had become dominated by diseases that - at first sight - had little to do with poverty or other forms of misery. They seemed to be caused by an affluent lifestyle, and were mainly chronic in character and thus led to a great demand for health care. Tackling cardiovascular disease and cancer required a new approach that ultimately - in the 1990s - came to be labelled 'new public health'. The philosophy of 'public hygiene' was refreshed and applied to the health problems of the second half of the 2oth century.

Like in the 19th century, the challenge was to find collective approaches that would reach sufficient numbers of people to ensure a population-wide impact. This had to involve massive behaviour change, for which the directive and sometimes authoritarian approach of social hygiene was no longer suitable. The new public health therefore incorporated the insights that had been developed within the field of 'health promotion', which used psychological and sociological insights to develop interventions and policies to change healthrelated behaviour. This implied, among other things, that health education had to be supported by changes in the environment, e.g., by changing food composition or regulating the sales of tobacco. ${ }^{76}$

The term 'new public health' has been retained for this overview to emphasize some of its innovative aspects, but in reality most professionals now use the term 'public health' tout court. Since World War II, the field has gone through considerable terminological confusion. This is due to the fact that collective approaches to population health problems have come to include such a wide variety of methods, and to involve such a wide range of disciplines, that it is often difficult to recognize public health's boundaries. ${ }^{77}$

The incorporation of health promotion is not the only important development of the field of public health of the last half-century. In addition to new methods of behaviour change many other new methods for improving population health became available, and are now seen as core components of public health. For example, screening has become a powerful tool in public health's

76 The term 'new public health' was elaborated in Frances Baum, The New Public Health: An Australian Perspective (Melbourne etc.: Oxford University Press, 1998). For the genesis of the concept, and its relationship with previous approaches to public health, see Niyi Awofeso, "What's New About the 'New Public Health'?, American Journal of Public Health 94, no. 5 (2004): 705-09.

77 This terminological confusion is reflected in frequent name-changes. For example, the United Kingdom adopted the term 'community medicine' in the 1970s, changed this into 'public health medicine' in the 1980s, and since then settled on 'public health' again, now conceived as a multidisciplinary field. 
toolbox. This includes screening for risk factors of disease, as in the case of detection of hypertension and high serum cholesterol, followed by dietary advice and/or drug treatment, as well as screening for early stages of disease, as in the case of mass screening for cervical and breast cancer, followed by further diagnosis and treatment. Another example of a new intervention option is accident prevention. Road traffic safety and prevention of drowning, poisoning, and falls have not only become highly effective, but also much needed in the face of the rising death toll from various causes of injuries. ${ }^{78}$

\section{The Impact of Public Health}

What has been the contribution of this expanding arsenal of public health interventions to long-term improvements in population health? As mentioned in Chapter 1, this has been the object of an important debate. This debate has, however, largely focused on a single country (the United Kingdom) and a somewhat limited period of time (mainly the second half of the 19th, and first decades of the 2oth century).

McKeown, in his interpretation of the mortality decline in England and Wales, not only concluded that medical care had made a negligible contribution, but also that public health measures (sanitation and other improvements in hygiene) had contributed very little. This was because they arrived long after mortality decline had set in, and could only have been responsible for the decline of mortality from diarrheal diseases. It could not have been responsible for the decline of respiratory tuberculosis which accounted for a much larger part of total mortality decline.

However, both McKeown's timing of mortality decline and his rejection of the role of public health measures in explaining the decline of tuberculosis mortality have become under serious attack. Due to fluctuations in mortality it is difficult to pin-point the exact year in which mortality definitely started to decline, and public health measures like isolation of tuberculosis patients and improvements of housing and working conditions may well have contributed to the decline of respiratory tuberculosis. ${ }^{79}$

$7_{8}$ The expanded scope of public health, and the widened arsenal of effective interventions, can easily be recognized in modern textbooks of public health, such as the (massive) Oxford Textbook of Public Health (Roger Detels et al., Oxford Textbook of Global Public Health, 5 ed. (Oxford etc.: Oxford University Press, 2015)).

79 These and several other criticisms of McKeown's analysis of mortality decline in England and Wales were published in 1988 by British historian Simon Szreter (Szreter, "Social Intervention"), and have since been widely accepted (see, e.g., Woods, Demography, Chapter 8$)$. 
Extending our scope over the whole period of three centuries covered by this book, and over the whole of Europe, as we do in the following chapters when we discuss this issue disease-by-disease, it becomes obvious that public health interventions have made substantial contributions to mortality decline. Britain was a special case, because it had relatively high tuberculosis mortality and like some other North-western European countries experienced an early mortality decline. The impact of public health measures is easier to discern in other European countries with a later mortality decline. Also, over the last decades many more studies have been done, providing convincing empirical evidence that specific public health interventions have had significant impacts on a range of health outcomes. ${ }^{80}$

Starting with 'medical police', it is difficult to say whether this contributed to the main achievement of the 18th century, i.e., the reduction of the frequency and amplitude of mortality crises. German-speaking countries, where these ideas originated, were not among the most advanced in terms of population health in this period. However, as we will see in Chapter 5 , the cordon sanitaire of the Habsburg Empire against the introduction of plague from the Ottoman Empire was a successful form of 'medical police'. The good performance of Sweden has also been attributed to the popularity in this country of ideas closely related to the concept of 'medical police'. Sweden was not only one of the first countries to create a national system of vital statistics (1748), but in response to the appalling mortality figures that this system revealed, it also created a tax-financed system of medical officers, midwives and hospitals throughout the country. ${ }^{81}$

More generally, the "eighteenth century campaign to avoid disease" has been credited with some first declines of mortality, for example from malaria due to the draining of swamps, although quantitative data are difficult to find. Furthermore, the introduction of smallpox inoculation in the 1720s, and of

8o Tuberculosis was more important as a cause of death in England than in some other European countries, such as Italy. Whereas the contribution of the broader group of infectious diseases to mortality decline was similar in both countries, the percentage contribution of respiratory tuberculosis was one-and-a-half times larger in England \& Wales; see Graziella Caselli, "Health Transition and Cause-Specific Mortality," in The Decline of Mortality in Europe, ed. Roger S. Schofield, David S. Reher, and Alain Bideau (Oxford: Clarendon Press, 1991).

81 For the effectiveness of the cordon sanitaire of the Habsburg empire, see Gunther E Rothenberg, "The Austrian Sanitary Cordon and the Control of the Bubonic Plague: 17101871," Journal of the History of Medicine and Allied Sciences 28, no. 1 (1973): 15-23. For Sweden's adoption of the principles of 'medical police', see Jan Sundin and Sam Willner, Social Change and Health in Sweden: 250 Years of Politics and Practice (Stockholm: Swedish National Institute of Public Health, 2007). 
smallpox vaccination in the early 1800 , often with strong government backing, has certainly made important contributions to mortality decline long before the 1840 (the starting-point of McKeown's mortality analyses). ${ }^{82}$

The impact of 'public hygiene' is somewhat easier to discern. McKeown acknowledged the role of sanitation in bringing down mortality from diarrheal diseases, but could only point to the correspondence of national mortality trends with the timing of introduction of Chadwick's 'sanitary idea'. Since then, many more detailed studies have been done, and have provided more robust evidence that introduction of sewage systems and/or piped drinking caused mortality to decline in many countries. ${ }^{83}$

When we lump together the period of 'social hygiene' with that of 'new public health', and assess the contribution of public health interventions developed during the 2oth century, the picture is very clear. Around the year 2000, the US Centers for Disease Control (CDC) celebrated the public health achievements of the 2oth century in a number of important overviews, of which most of the conclusions also apply to European countries. Improvements in work safety, mother and child care, vaccination and other forms of infectious disease control, quality and safety of food, and quality of housing undoubtedly contributed to mortality decline, particularly in the first half of the century.

Similarly, some of the newer approaches have had an important impact on population health in Europe during the second half of the 2oth century. The success of the decline of ischaemic heart disease mortality has many fathers, but one of them is health promotion, e.g., systematic efforts to reduce smoking and make diets healthier. Tobacco control has contributed to stopping the rise

82 For the mortality effects, see Riley, Campaign, Chapter 6. The effects of smallpox inoculation and vaccination will be discussed in more detail in Chapter 4.

83 A review by Dutch demographer Frans van Poppel, published in 1997, found that the evidence for an effect of improved drinking water supply on infant and childhood mortality was rather mixed (Frans van Poppel and Cor van der Heijden, "The Effects of Water Supply on Infant and Childhood Mortality," Health Transition Review 7, no. 2 (1997): 113-48). Since then, several more rigorous studies have been published, finding more convincing effects of either improved drinking water supply (David Cutler and Grant Miller, "The Role of Public Health Improvements in Health Advances," Demography 42, no. 1 (2005): 1-22), or sewage systems (Lionel Kesztenbaum and Jean-Laurent Rosenthal, "Sewers' Diffusion and the Decline of Mortality: The Case of Paris, 1880-1914," Journal of Urban Economics 98 (2017): 174-86), or investments in sanitation more generally (Frances Bell and Robert Millward, "Public Health Expenditures and Mortality in England and Wales, 18701914," Continuity and Change 13, no. 2 (1998): 221-49). The implementation of sanitary reform often gained speed only towards the end of the 19th century. 
of lung cancer, at least among men, and accident prevention has contributed to sometimes spectacular declines in injury mortality. ${ }^{84}$

Some European countries, such as the former Soviet Union and its satellites in Central-eastern and South-eastern Europe, have been unable or slow to make the switch from the 'old public health', with its emphasis on infectious diseases and paternalistic methods, to the 'new public health'. These countries have also been unable or slow to reduce ischaemic heart disease mortality. Also, differences between countries in trends for cervical and breast cancer mortality are partly due to differences in implementation of population-based screening programs for these diseases. ${ }^{85}$

Plate 5 has miniature portraits of a few figureheads of European public health mentioned in this Chapter or elsewhere in this book.

\section{A Short History of Medical Care}

Writing a "short history of medical care," as this section's title suggests, is much more difficult than writing a "short history of public health." Medical care, with its huge knowledge base, multiple specializations and complex organization, is a much larger field than public health. We will therefore have to reduce the scope of this "short history" to make the exercise manageable. We will do this by focusing on what mattered for improving population health.

Scientific breakthroughs have, of course, been important but are only one of the factors that have increased the impact of medical care on population health. Surprisingly, the role of scientific medicine is still disputed. Writing in 1997, historian Roy Porter in his The Greatest Benefit to Mankind: a Medical History of Humanity from Antiquity to the Present notes that "medicine's historical balance sheet [is] hard to assess. [...] Its standing is now highly contested. Never has it achieved so much or attracted so much suspicion." Echoing McKeown, he writes that

the facts indicate how little medicine weighs in the balance of health. [...] We have invested disproportionately in a form of medicine ('Band Aid'

84 For the CDC study, see Centers for Disease Control and Prevention, "Ten Great Public Health Achievements - United States, 1900-1999," MMWR. Morbidity and mortality weekly report 48, no. 12 (1999): 241; John W. Ward and Christian Warren, Silent Victories (New York etc.: Oxford University Press, 2006). For an update, see Centers for Disease Control and Prevention, "Ten Great Public Health Achievements - United States, 2001-2010," MMWR. Morbidity and mortality weekly report 6o, no. 19 (2011): 619 .

85 See, e.g., Ahti Anttila and José M. Martin-Moreno, "Cancer Screening," in Successes and Failures of Health Policy in Europe, ed. Johan P. Mackenbach and Martin McKee (Maidenhead: Open University Press, 2013). 

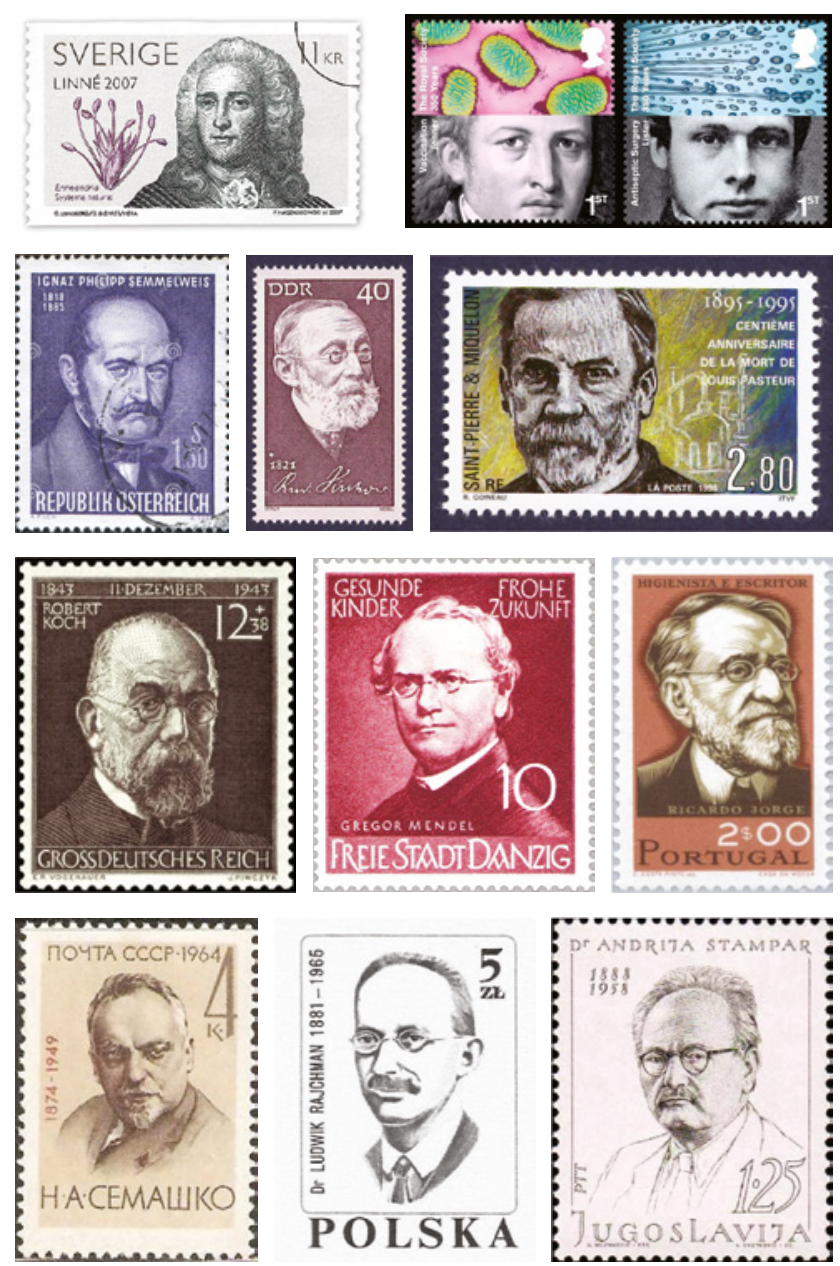

PLATE 5 European public health history on 2oth century postage stamps

Many 'standard bearers' of public health have been immortalized on postage stamps. From left to right: Top row: Carl von Linné (one of the earliest disease classifications, Sweden, 18th century), Edward Jenner (smallpox vaccination, Britain, 19th century), Joseph Lister (antiseptic surgery, Britain, 19th century). Second row: Ignaz Semmelweis (cause of puerperal fever, Austria-Hungary, 19th century), Rudolf Virchow (pathology and public health, Germany, 1gth century), Louis Pasteur (bacteriology, France, 19th century). Third row: Robert Koch (bacteriology, Germany, 19th century), Gregor Mendel (genetics, Austria-Hungary, 19th century), Ricardo Jorge (public health, Portugal, early 2oth century). Bottom row: Nicolai Semashko (public health, Soviet Union, 2oth century), Ludwik Rajchman (public health, Poland, 2oth century), Andrija Stampar (public health, Yugoslavia, 2oth century) 
salvage) whose benefits often come late, which buy a little time, and which are easily nullified by external, countervailing factors. ${ }^{86}$

Is this a fair assessment? In the next section I will show that it is not, but first it needs to be understood that the population health impact of medical care is determined by three, equally important factors. The first is availability of effective treatments, as resulting from the scientific breakthroughs and other advances that form the core of the usual histories of medicine. The second is coverage of the relevant patient groups, as determined by diffusion of the innovation among medical professionals and by access of patients to the health care system. The third is quality of application, which is dependent on, among others, training, experience and guideline adherence of professionals and on patient compliance. Over time, each of these three factors has changed, mostly in a favourable direction albeit with large differences in tempo between countries. ${ }^{87}$

There can be little doubt that the availability of effective treatments has increased enormously. It is not necessary to go into the details of Porter's 700+ pages of medical history to identify the main advances in medical treatment over the last three centuries, at least if we restrict ourselves to the advances that have demonstrably improved patient outcomes. Until the late 1930s, advances in specific treatments numbered less than ten, and included a few traditional remedies derived from plants (digoxin against heart failure, aspirin against various pains, and quinine against malaria), antitoxins against diphtheria and tetanus and salvarsan against syphilis, some hormone replacements (insulin against diabetes and thyroxin against hypothyroidism), and sulphonamides (against pneumonia and a few other infections). In addition, there had been some generic advances in fields like obstetrics, surgery, trauma, and nursing care. ${ }^{88}$

Starting around World War II, however, progress accelerated and a whole range of new, specific therapeutics became available. British general practitioner and author James Le Fanu has listed the breakthroughs that brought several important diseases under medical control. These include penicillin

86 Cited from Porter, Greatest Benefit, Chapter XxII.

87 This idea that the population health impact of medical care is dependent on 'innovation', 'coverage' and 'quality' was developed by British public health scientist and advocate Martin McKee; see Johan P. Mackenbach et al., "Using 'Amenable Mortality' as Indicator of Healthcare Effectiveness in International Comparisons," Journal of Epidemiology and Community Health 67, no. 2 (2013): 139-46.

88 Henry H. Dale, "Advances in Medicinal Therapeutics," British Medical Journal, no. 4644 (1950): $1-7$. 
(against various infectious diseases, 1941), cortisone (against immunological and many other diseases, 1949), streptomycin (against tuberculosis, 1950), chlorpromazine (against depression, 1952), artificial ventilation and intensive care (against poliomyelitis and other life-threatening conditions, 1952), open heart surgery (to replace rheumatic heart valves or lay bypasses around clotted coronary arteries, 1955), hip replacement (against hip fractures and arthrosis, 1961), kidney transplantation (against chronic kidney diseases, 1963), antihypertensive drugs (against stroke and other cardiovascular diseases, 1964), and chemotherapy (against childhood cancer, 1971). ${ }^{89}$

Although Le Fanu, writing in the 199os, thought that the era of progress had ended due to a slowing down of the development of new effective drugs, it is not difficult to see continued progress in a number of fields. In addition to life support and bypass surgery, the treatment of acute myocardial infarction now includes thrombolysis and percutaneous coronary interventions (both introduced in the 1980s), as well as drug treatment to prevent re-thrombosis, as a result of which survival has increased remarkably. Statins were developed to lower serum cholesterol (1980s), which helped to reduce incidence as well. The management of acute stroke has also improved considerably due to the introduction of comprehensive stroke centres (1990s), as has the management of injury. After the development of effective chemotherapy against acute lymphoblastic leukaemia and other childhood cancers, remarkably effective therapies were developed against other forms of cancer, such as Hodgkin's disease and testicular cancer (1970s). More modest improvements in the treatment of breast cancer (1980s) and colorectal cancer (1990s) - to mention two important examples - have also contributed to a gradual increase in cancer survival. ${ }^{90}$

These are just the specific therapeutics which are relatively easy to pinpoint, but in addition to these, many more general advances were made. For example, due to the introduction of asepsis, blood transfusion and antibiotics surgery became safer, and improvements in surgical techniques then made it possible to treat a wide range of diseases, from appendicitis and cholecystitis to cancers and eye cataracts. While the examples given mostly relate to potentially fatal diseases, important advances have also been made in pain relief and treatment or rehabilitation of sensory and motor disabilities. ${ }^{91}$

89 James Le Fanu, The Rise and Fall of Modern Medicine (London: Little Brown \& Co, 1999).

9o See, for example, Ellen Nolte and Martin McKee, Does Health Care Save Lives? Avoidable Mortality Revisited (London: The Nuffield Trust, 2004); Mackenbach et al., "Using 'Amenable Mortality' as Indicator of Healthcare Effectiveness."

91 All these advances should be weighed against the increase in 'iatrogenic disease' resulting from the widening scope and expanding use of medical care, but seen over a longer 
These innovations can only affect population health if they achieve sufficient coverage, and are applied to all patients whose health problems can be alleviated by the new treatment. Whereas the history of medical innovation can be written from a universal standpoint - streptomycin, blood transfusion and stroke units were invented only once - the history of treatment coverage is much more locally specific. New treatments diffuse like all innovations, with early and late adopters, both among countries and within countries among population groups and professionals. Studies show that even in the last decades of the 2oth century, and even in North-western Europe, this diffusion was often a lengthy process taking a decade or more before the last country had introduced the innovation. Between introduction and full use of the innovation, often another decade or more had to pass. ${ }^{92}$

When Europe as a whole is considered, differences in uptake of new medical treatments are even larger. Southern European countries used to be late adopters as compared to North-western European countries, and so were CentralEastern, South-eastern and Eastern Europe under communism. The latter did not, or only with much delay, adopt the advances in medical treatment which were developed in the West. Although antibiotics such as penicillin and streptomycin diffused rapidly towards Central-Eastern European countries and the Soviet Union in the 1940s, modern drugs developed from the 196os onwards, such as anti-hypertensive drugs, cancer chemotherapy, and cimetidine (against peptic ulcer), did not. This was due to international isolation (e.g., inability to read the English-language literature) as well as to a different scientific paradigm. ${ }^{93}$

period the benefits have almost always outweighed the harms; see John P. Bunker, "The Role of Medical Care in Contributing to Health Improvements within Societies," International Journal of Epidemiology 30, no. 6 (2001): 1260-63.

92 See, e.g., Ragnar Westerling et al., "The Timing of Introduction of Pharmaceutical Innovations in Seven E Uropean Countries," Journal of Evaluation in Clinical Practice 20, no. 4 (2014): 301-10, for a study of six European countries between the 1970s and 1990s. The delay in introduction varied between 8 years for antiretroviral drugs (against AIDS) and 22 years for cisplatin (against testicular cancer), and the subsequent delay between introduction and peak use varied between a few years and more than 20 years.

93 The study by Westerling et al., "Timing of Introduction" found that, whereas Spain still lagged behind North-western European countries in the 1970s, it no longer did so in the 1980s and 1990s. In Estonia most modern drugs were only introduced after independence in the early 1990s. On the isolation of Soviet medicine, and the role of a scientific paradigm based on communist orthodoxy instead of empirical evidence, see Martin McKee, "Cochrane on Communism," International Journal of Epidemiology 36, no. 2 (2007): 269-73. 
Achieving sufficient coverage is not only a matter of diffusion of the innovation among medical professionals, but also of patient access. Over time, patient access to medical care has increased considerably. This was due to a combination of increased supply (e.g., rising numbers of doctors, hospital beds, pharmaceutical drugs, equipment) and reduced financial barriers to care utilisation. The expansion of health care into an economic sector absorbing more than $10 \%$ of national income has created an enormous machinery to deliver medical treatment. This happened mostly in the second half of the 2oth century: health care still accounted for less than $1 \%$ of national income in the 1930s, but after World War II health expenditure exploded and now often accounts for more than $10 \% .{ }^{94}$

This was facilitated by another factor crucial to coverage: the introduction and expansion of social insurance schemes and (in some countries) a taxbased national health service. The origins of health insurance go back to the Middle Ages, when guilds created mutual assistance associations which - because of their restriction to guild members - covered less than $5 \%$ of the population. When the guilds were abolished, voluntary health insurance continued ('sick funds') to exist in various forms, but participation was usually highly restricted.

Germany, under its chancellor Otto von Bismarck $\left(1815^{-1898)}\right.$, was the first European country to place these sick funds under the authority of the state, and to create a legal framework making health insurance compulsory for all workers in 1883. Most other countries in North-western Europe followed the German example, with coverage often rising to around $20 \%$ of the population just before World War I, and to around $40 \%$ just before World War II.

It was only in the aftermath of this war, that governments decided to expand coverage to all workers, their dependants, the unemployed and pensioners. Most countries in North-western Europe achieved this without abandoning a social insurance system, by creating a complex regulatory framework and adding heavy state subsidies. However, a few countries chose to switch to a simpler tax-based 'national health service': the United Kingdom did this in 1946 and the Nordic countries followed in the 1960 s and 1970 s. This ultimately raised coverage to more than $90 \%$ of the population in the $1970{ }^{95}$

94 For a long-term history of spending on health care, see Vito Tanzi and Ludger Schuknecht, Public Spending in the 2oth Century (Cambridge etc.: Cambridge University Press, 2000).

95 A good introduction to the history of social health insurance in Europe is Richard B. Saltman and Hans F.W. Dubois, "The Historical and Social Base of Social Health Insurance Systems," in Social Health Insurance Systems in Western Europe, ed. Richard B Saltman, R. Busse, and J. Figueres (Maidenhead: Open University Press, 2004), from which the figures cited in the text have been taken. Some studies have found that stronger expansion 
Countries in other European regions often lagged behind considerably. In Southern Europe, coverage rates remained low until the 196os, but climbed rapidly in the following decades, often coinciding with the switch from dictatorship to democracy, and often based on the introduction of a tax-based national health system. In Central-eastern, South-eastern and Eastern Europe, coverage was raised to nominally $100 \%$ with the advent of communism. Under communism, everyone was theoretically entitled to free medical care, but quality of services was usually low, and informal 'under-the-table' payments were often required to obtain better quality care. After the collapse of the Soviet Union, most formerly communist countries rapidly transitioned to some kind of social health insurance system, but with vastly reduced government funding and high user fees. ${ }^{96}$

Finally, quality of delivery is the third essential ingredient of the success of medical care in improving population health. Quality of care delivery can change over time, and vary between countries, independent of the diffusion of innovations and independent of access to care. For example, the Soviet Union, as part of its modernization efforts and ambition to provide universal access to health care, succeeded in a 20 -fold rise of its number of medical doctors between 1913 and 1963. This must have made a contribution to improving population health, but standards of medical training were low, doctors were badly paid, and incentives were mainly to raise quantity of production, not quality. Russia and other former Soviet republics are still suffering from this legacy. ${ }^{97}$

More generally, however, quality of delivery has probably increased over the 2oth century, as a result of better training of medical personnel, increased access of medical professionals to the international literature, and the rise of evidence-based medicine which - at least in some European countries - has

of health insurance coverage was associated with stronger mortality decline; see Calman R. Winegarden and John E. Murray, "The Contributions of Early Health-Insurance Programs to Mortality Declines in Pre-World War I Europe," Explorations in Economic History 35, no. 4 (1998): 431-46.

96 On the historical increase in population health coverage, see Khalid Malik, Human Development Report 2014 (New York: United Nations Development Programme, 2014), Fig. 4.2. On the transition to social health insurance in Eastern Europe, see Hugh R. Waters et al., "Health Insurance Coverage in Central and Eastern Europe: Trends and Challenges," Health Affairs 27, no. 2 (2008): 478-86; Bernd Rechel and Martin McKee, "Health Reform in Central and Eastern Europe and the Former Soviet Union," Lancet 374, no. 9696 (2009): 1186-95.

97 On the successes and failures of the Soviet health care system, see Mark G. Field, Soviet Socialized Medicine: An Introduction (New York: Free Press, 1967). For the persistence of this legacy, see, e.g., Bernd Rechel et al., "Health and Health Systems in the Commonwealth of Independent States," Lancet 381, no. 9872 (2013): 1145-55. 
increased homogeneity of medical practice through the use of clinical practice guidelines.

\section{The Role of Medicine}

McKeown, echoed by Porter and many others, has argued that medical care made only a small contribution to the historical decline of mortality, because most of the decline of infectious diseases antedated the introduction of specific medical interventions, such as antibiotics. In his view, therefore, the "role of medicine" should be modest: "to assist us to come safely into the world and comfortably out of it, and during life protect the well and care for the sick and disabled."98

In the 40 years that have passed since his work was published, it has become clear that medical care did have some impact before the introduction of antibiotics, and that, although these and other effective medical technologies arrived late in the historical decline of mortality, they did contribute to a further lowering of mortality. However, it is less clear how important exactly the contributions of medical care have been..$^{99}$

When addressing this question from a European perspective it is again important to note that the British experience is unlikely to be generalizable. As mentioned above, not only was the cause-of-death composition of mortality in England different from that in many other European countries, but like other countries in North-western Europe, England had also experienced an early mortality decline. This left less scope for medical care to contribute than in other parts of Europe, where mortality from infectious diseases was still high in the middle of the 2oth century.

A simple look at Figure 1 shows that at the end of the 1930s life expectancy at birth in Europe varied between less than 40 and more than 60 years, with the United Kingdom at the upper end of the distribution (6o years for men, 64 years for women). For countries at the lower end of the distribution, the scope for antibiotics and other medical innovations to contribute to increases in life expectancy was therefore much larger. Also, since the early 1970s, where

98 McKeown's The Role of Medicine - Dream, Mirage or Nemesis was published in 1976, 30 years into the post-World War II period of expanding medical care (McKeown, Role). The quote is from p. 173. McKeown's attack on the idea that modern medicine had made important contributions to life extension was part of his agenda to re-direct emphasis towards softer goals; see, e.g., Stephen J. Kunitz, "Explanations and Ideologies of Mortality Patterns," Population and Development Review 13, no. 3 (1987): 379-408.

99 Mackenbach, "Contribution" reviews these critiques. See also some disease-specific chapters in Part II. 
McKeown's analyses ended, life expectancy has increased by another 10 years in many countries, raising the possibility of new contributions of medical care.

Three pieces of evidence suggest that medical care did not only have a measurable impact, but that this impact was substantial, both in absolute and relative terms. These include more detailed analyses of the impact of medical innovations on cause-specific mortality; empirical analyses of the contributions of declines in 'amenable' mortality to total mortality decline; and model-based assessments of the contribution of medical care to total mortality decline.

Sometimes, the impact of medical innovations can be observed in the form of an immediate change in cause-specific mortality. This occurs when a new treatment has a large effect, when it rapidly reaches patients with the relevant conditions, and when quality issues do not dilute the effect. This is rather exceptional - mostly, the expectation should be for more gradual changes but it does sometimes happen.

The prime example is the introduction of sulphonamides (1935) and antibiotics (1944)(Plate 6). Studies from several countries in North-western Europe have found that, after the introduction of these drugs, the rate of decline for many infectious diseases accelerated. For many infectious diseases there was also an instantaneous, stepwise decrease in mortality coinciding with the introduction of antibiotics. These effects - already substantial in North-western Europe - were considerably larger in other European countries, where mortality from infectious diseases was still very high in the $1940{ }^{100}$

Instantaneous effects have also been found for a few other innovations. The introduction of integrated chemo- and radiotherapy against Hodgkin's disease in the early 196os was almost immediately followed by rapid mortality decline in many countries in North-western and Southern Europe, but only much later in Central-eastern, South-eastern and Eastern Europe. Similarly, the introduction of platinum-based chemotherapy against testicular cancer in the 1970 s was followed by a reversal from rising to declining mortality from this disease

100 For example, in the Netherlands mortality from all infectious diseases together declined by $4 \%$ per year before the introduction of antibiotics, and by $10 \%$ per year after the introduction; see Johan P. Mackenbach and C.W.N. Looman, "Secular Trends of Infectious Disease Mortality in the Netherlands, 1911-1978," International Journal of Epidemiology 17, no. 3 (1988): 618-24, and Chapter 5 . Similar findings were reported from Sweden and Finland (Elina Hemminki and Anneli Paakkulainen, "The Effect of Antibiotics on Mortality from Infectious Diseases in Sweden and Finland," American Journal of Public Health 66, no. 12 (1976): 1180-84) and from England \& Wales (Galbraith and McCormack, "Infection in England and Wales", passim). 


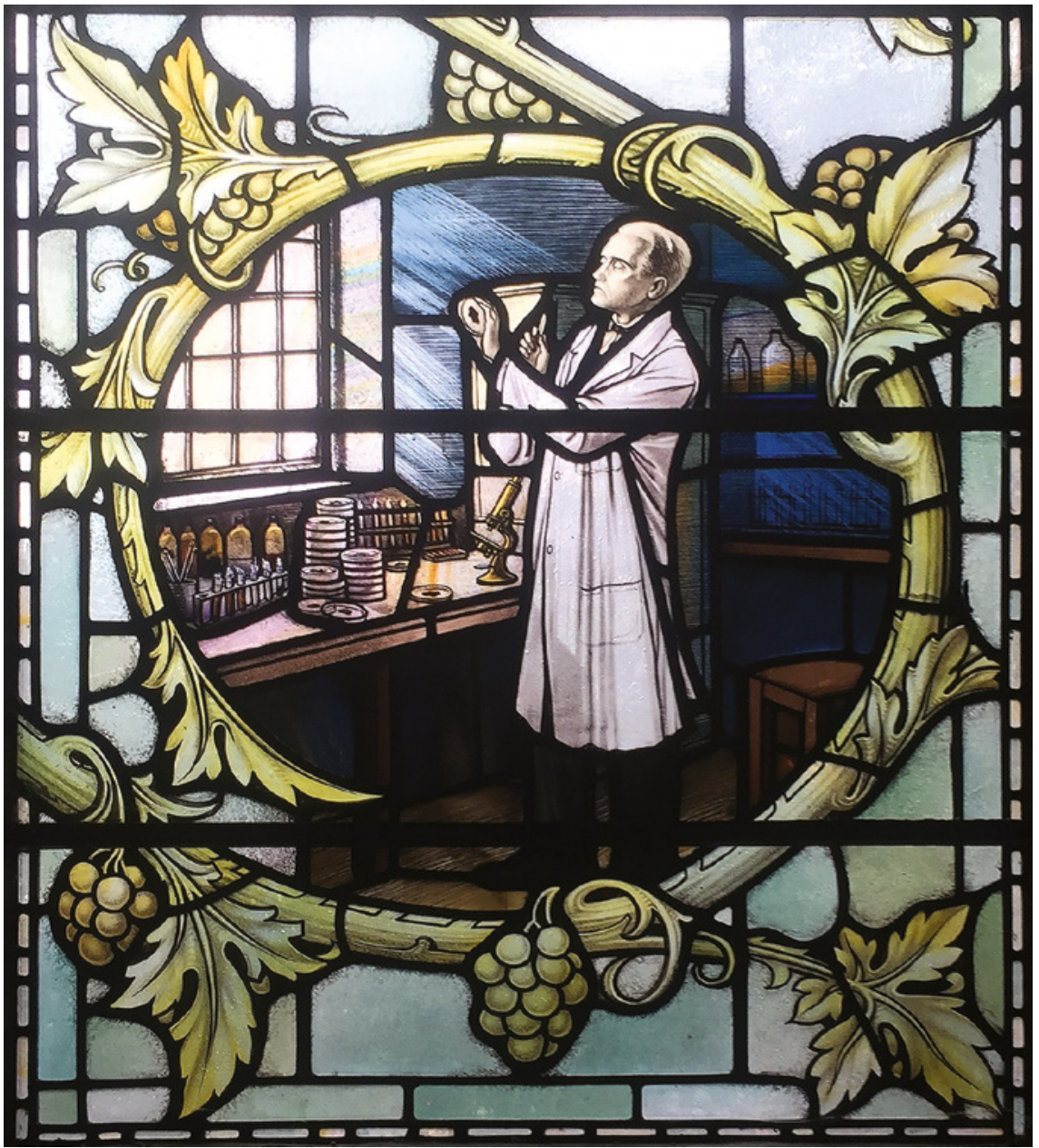

PLATE 6 Alexander Fleming on a stained glass window in St. James's Church (London), $195^{2}$

Sir Alexander Fleming (1881-1955) accidentally discovered the bactericidal properties of penicillin in 1928. This stained glass window shows Fleming at work in his laboratory, which was located in the vicinity of this church. Inadvertently, it illustrates the almost religious worship of modern medicine in a secularized society HTTPS://COMMONS.WIKIMEDIA.ORG/WIKI/FILE:ALEXANDER_ FLEMING_STAINED_GLASS_WINDOW.JPG (CCo 1.0; ACCESSED 18/10/2019) 
in North-western and Southern Europe, only to be followed much later in the rest of Europe. ${ }^{101}$

Less clear-cut changes have been found for breast, colorectal and other cancers, as well as for innovations in treatment of cardiovascular diseases. This can be explained by the reasons mentioned in the previous section, and by the fact that many improvements in treatment (and sometimes prevention) occurred simultaneously, so that it is impossible to disentangle their effects. Other approaches must therefore be used to estimate the effect of medical care on population health. ${ }^{102}$

One, frequently used approach is to simply take the trends in mortality from conditions which have become amenable to medical intervention, and to compare these to the trends in mortality from non-amenable conditions or total mortality. Examples of causes of death usually included in selections of 'amenable' causes are tuberculosis, pneumonia, Hodgkin's disease, appendicitis, and maternal and perinatal deaths. ${ }^{103}$

Trends in mortality from these conditions have indeed often been rapidly downward over the past half-century, and more so than trends in mortality from non-amenable conditions. This suggests that general improvements in living conditions or behavioural risk factors cannot fully explain their decline, and that medical care also made a contribution. Within Europe, there have been important differences in decline of these conditions, along expected lines. For example, during the communist period declines of mortality from amenable conditions have been much less in Central-eastern, South-eastern and Eastern Europe, and it is only recently that some of this disadvantage has been recovered. Higher mortality from 'amenable' conditions in these parts of

101 For trends in mortality from a range of cancers in many European countries, including Hodgkin's disease and testicular cancer, see Fabio Levi et al., "Cancer Mortality in Europe, 1990-1994, and an Overview of Trends from 1955 to 1994," European Journal of Cancer 35, no. 10 (1999): 1477-516. See also Fabio Levi et al., "Trends in Mortality from Hodgkin's Disease in Western and Eastern Europe," British Journal of Cancer 87, no. 3 (2002): 291-93; Peter Boyle, Patrick Maisonneuve, and Stanley B. Kaye, "Therapy for Testicular Cancer in Central and Eastern Europe," Lancet 335, no. 8696 (1990): 1033.

102 For two attempts to measure the impact of innovations in treatment of cancer and cardiovascular disease in European countries, see Rasmus Hoffmann et al., "Innovations in Health Care and Mortality Trends from Five Cancers," International Journal of Public Health 59, no. 2 (2014): 341-50; Rasmus Hoffmann et al., "Innovations in Medical Care and Mortality Trends from Four Circulatory Diseases," European Journal of Public Health 23, no. 5 (2013): $85^{2-57}$.

103 For the origins of this approach, see David D. Rutstein et al., "Measuring the Quality of Medical Care: A Clinical Method," New England Journal of Medicine 294, no. 11 (1976): 582-88; Walter W. Holland, “The 'Avoidable Death' Guide to Europe," Health Policy 6, no. 6 (1986): $115^{-17}$. 
Europe, even after risk factor standardization, persists until the present day, and accounts for a substantial part of the differences in life expectancy with North-western and Southern Europe. ${ }^{104}$

The results of these studies can be used for a rough estimate of the contribution of improvements in medical care to total mortality decline. For example, between the early 1950 and early 1980 s declines of mortality from 'amenable' conditions added 3 and 4 years, respectively, to life expectancy at birth of men and women in the Netherlands. Because life expectancy actually increased by only 2 and 6 years, improvements in medical care more than compensated for unfavourable trends for other causes of death among men (such as ischaemic heart disease and road traffic injury), and accounted for two-thirds of the total increase in life expectancy among women. ${ }^{105}$

That improvements in medical care have probably made a substantial contribution to recent declines in mortality (and increases in life expectancy) has also been shown in model-based calculations. One study from the United States combined results from Randomized Controlled Trials, in which the effect of specific interventions on mortality among study participants had been measured, with data on the coverage of these interventions in the population. It concluded that between $195^{\circ}$ and 1989 , medical treatments had increased average life expectancy by 4.5 years. ${ }^{106}$

A somewhat similar approach was applied in the Netherlands. In this case, the conclusion was that, between the early 1950s and early 2000s, improvements

104 For analyses showing a more rapid decline of 'amenable' mortality, see Nolte and McKee, Does Health Care Save Lives; John Charlton and Ramon Velez, "Some International Comparisons of Mortality Amenable to Medical Intervention," British Medical Journal 292, no. 6516 (1986): 295-301. Less rapid decline in Central-eastern Europe between the 1950s and late 1980 s was documented in Richard J. Boys, Donald P. Forster, and Peter Jozan, "Mortality from Causes Amenable and Non-Amenable to Medical Care: The Experience of Eastern Europe," British Medical Journal 303, no. 6807 (1991): 879-83. In Russia, 'amenable' mortality decline stagnated between the 1960 and 1980 , reversed into increasing mortality in the 199os, and then started to decline again (Evgueni M. Andreev et al., "The Evolving Pattern of Avoidable Mortality in Russia," International Journal of Epidemiology 32, no. 3 (2003): 437-46).

105 As estimated in Johan P. Mackenbach et al., "Post-1950 Mortality Trends and Medical Care," Social Science \& Medicine 27, no. 9 (1988): 889-94. In Mackenbach, “Contribution”, which reported on another study for the Netherlands spanning the period between 1875 and 1970, and therefore included some earlier innovations as well, improvements in medical care accounted for between 5 and $20 \%$ of total mortality decline.

106 This study also estimated the effect of improvements in medical care on quality of life in non-fatal conditions (John P. Bunker, Howard S. Frazier, and Frederick Mosteller, "Improving Health: Measuring Effects of Medical Care," Milbank Quarterly 72, no. 2 (1994): 225-58). 
in medical care for infectious diseases, cardiovascular diseases and cancer contributed around 4 years to life expectancy at birth among men and women. This is about half of the total increase in life expectancy over that period. ${ }^{107}$

107 Willem J. Meerding et al., Hoe Gezond Zijn De Zorguitgaven?, vol. 6, Zorg Voor Euro's, (Bilthoven: Rijksinstituut voor Volksgezondheid en Milieu, 2007). 